Sign Systems Studies 49(1/2), 2021, 12-62

\title{
Anticipating the societal transformation required to solve the environmental crisis in the 21 st century
}

\section{Morten Tønnessen ${ }^{1}$}

\begin{abstract}
This article introduces an ecosemiotic approach to the two great challenges facing humanity in the 21st century: solving an escalating environmental crisis, while also safeguarding and further improving human living conditions. An ecosemiotic framework for the study of societal transformations is presented and political and other normative aspects of what I call transformative semiotics are discussed. This envelops socio-cultural and socio-ecological developments framed in terms of umwelt theory and Deep Ecology. In the long run, developments in human ecology as reflected in our changing relations to non-humans are expressed in the umwelt trajectory of humankind. The question of how the environmental crisis can best be solved is therefore tantamount to the question about what direction the human umwelt trajectory should take in this century. I outline different plausible umwelt scenarios for human ecology in the 21 st century, focused on business-as-usual, ecomodernist and Deep Ecology scenarios. In a concluding discussion on technology and sustainability, the scenario development eventually includes a distinction between flexible and inflexible development paths.
\end{abstract}

Keywords: global human ecology; societal transformation; umwelt theory; environmental crisis; transformative semiotics; ecosemiotics; Deep Ecology; ecomodernism

\section{Introduction}

Two great challenges are facing humanity in the 21 st century: solving an escalating environmental crisis, and safeguarding and further improving human living conditions. These two challenges are interrelated. As recognized by the United Nations (UN) with its 2030 Agenda for Sustainable Development ${ }^{2}$, the

1 Department of Social Studies, University of Stavanger, Stavanger, Norway; e-mail: mortentoennessen@gmail.com.

2 United Nations 2015a. Transforming our world: The 2030 Agenda for Sustainable Development. Resolution A/RES/70/1. Adopted by the General Assembly on 25 September 2015 can be found at https:/www.un.org/en/development/desa/population/migration/generalassembly/ docs/globalcompact/A_RES_70_1_E.pdf. 
great challenges of our time should be approached in conjunction. However, current policy strategies, such as the UN's Sustainable Development Goals (United Nations 2015a), rely on an outdated model of development that has not proven to be environmentally sustainable (O'Neill et al. 2018). This calls for a critical discussion of the current and alternative models of development.

This article attempts to address these grand challenges from semiotic perspectives, notably that of Jakob von Uexküll's umwelt theory (Uexküll 1921, 1928, 1982[1940]). The main idea of the umwelt theory is that the lives of all humans, other animals and unicellular organisms play out in distinctive subjective worlds, or umwelten, which can be understood in semiotic terms. As Kull (2010:44) points out, "Uexküll saw as a major task of his scientific approach to describe the multispecies community of organisms on the basis of relations between Umwelten of different species of organisms" and was particularly interested in "the relations the organisms have between each other". In our time, it is the relations between humans and non-humans that are the most telling ones with regard to the ecological situation.

I have proposed the concept of umwelt trajectory, which is "the course through evolutionary (or cultural) time taken by the Umwelt of a creature, as defined by its changing relations with the Umwelten of other creatures" (Tønnessen 2014: 159). Here 'the umwelt of a creature' can be understood e.g. as the umwelt of an individual organism, of a population, or of a species, making the notion applicable on various levels of biological organization. In this article, I apply the 'umwelt trajectory' perspective on the human species in an analysis of the future societal transformation that is required to solve the environmental crisis in the 21st century in a way that is consistent with sustained human development. Key questions include: how should our relations to non-humans change, in order to secure environmental sustainability? How can improved living conditions for humans be pursued while society is being made environmentally sustainable?

The task of "solving" the environmental crisis in the 21 st century might sound overambitious. However, this way of framing environmental issues can be justified by reference to the fact that today's escalating environmental crisis involves elements of being an existential crisis for humanity and several other species. Developments in human ecology in this century will be decisive for living conditions in the longer term. The most worrying prospects are related to the danger that we might be crossing thresholds that represent tipping points, leading, for instance, to self-reinforcing climate change or a "die-back" of the Amazon rainforest (Nobre, Sampaio, Salazar 2007). In light of such prospects, addressing the environmental crisis in a meaningful way requires that the crisis be solved, by and large, over the next few generations. On the other hand, "solving" the crisis in this century does not mean that our actions will have no longer-term consequences, 
nor that future generations of human beings beyond the 21st century will have no more environmental issues to deal with. What it does imply, however, is that there will no longer be societal dynamics in place that routinely causes an escalating crisis that we risk losing control over.

The current article should be read in the context of two other recent studies, namely "What can be known about future Umwelten?" (Tønnessen 2019) and "Current human ecology in the Amazon and beyond: A multi-scale ecosemiotic approach" (Tønnessen 2020). The former of these develops theoretical foundations for umwelt futurology, the study of future umwelten, while the latter suggests a methodology for multi-scale ecosemiotic studies of human ecology, facilitating ecosemiotic studies ranging from the local to the global that have umwelt theory as their basis. This third article develops and discusses scenarios for global human ecology in the 21 st century, building on the two earlier articles. As a whole, these three articles can be seen as an extension of my work on umwelt transitions/environmental change (Tønnessen 2009) and umwelt trajectories (Tønnessen 2014) in that they make contemporary umwelt theory more applicable to the studies of near-future global human ecology.

Along with umwelt theory, this article rests on a preference for Deep Ecology (as an environmental philosophy developed in Arne Næss 1973, 1989, 1993) over ecomodernism with its more technology-oriented approach to environmental problems (Asafu-Adjaye et al. 2015³). Deep Ecology is concerned with getting to the root causes of the environmental crisis and identifies required changes in the worldview, values, and behaviours of humans. Connections or possible interfaces between Deep Ecology and ecosemiotics (for the latter, see Kull 1998; Nöth, Kull 2000; Nöth 1998, 2001; Maran, Kull 2014) that have previously been investigated in e.g. Tønnessen 2003; Kull, Kotov, Keskpaik 2004; Kull 2011, and Levesque 2016 are reviewed in the section "An ecosemiotic framework for the study of societal transformations". Arne Næss (1995[1992]) was concerned with taking a longterm view on the environmental crisis at the expense of short-term thinking and solutions. Stating that he was a "convinced optimist - when it comes to the 22nd Century" (Næss 1995[1992]: 463), he stressed that the "realization of what we call wide ecological sustainability of the human enterprise [...] may take a long time [...] How much is left of nature obviously depends upon what we do today and tomorrow" (Næss 1995[1992]: 464). This means that the sooner we act appropriately, the more can be saved. Wide ecological sustainability is here understood as

3 Asafu-Adjaye, John; Blomqvist, Linus; Brand, Stewart; Brook, Barry; DeFries, Ruth; Ellis, Erle; Foreman, Christopher; Keith, David; Lewis, Martin; Lynas, Mark; Nordhaus, Ted; Pielke, Roger Jr.; Pritzker, Rachel; Roy, Joyashree; Sagoff, Mark; Shellenberger, Michael; Stone, Robert; Teague, Peter 2015. An Ecomodernist Manifesto can be found at www.ecomodernism.org. 
entailing a "change ('development') in life conditions on the planet" that "is such that it ensures the full richness (abundance) and diversity of life-forms on the Earth" (Næss 1995[1992]: 464). This conception of sustainability contrasts with a "narrow" concept of ecological sustainability" according to which sustainability is achieved if there are policies in place that "will make ecological catastrophes affecting narrow human interests unlikely". The distinction between the wide and the narrow ecological sustainability relates to Næss' distinction between the deep and the shallow ecological movement and their respective goals. In light of Næss' longterm optimism, a central question is: "How far down are we going to sink before we start heading back up in the twenty-second century? How far must we fall before there is a clear trend toward decreasing regional and global ecological unsustainability?” (Næss 1995[1992]: 465). In Næss' vision of the future, the turning point, the change of direction, will realistically occur at some point during the 21 st century, though this will also represent a low point with respect to ecological devastation.

The choice of analysing the positions associated with ecomodernism and Deep Ecology from among all the voices in the environmental discourse can be justified by the useful contrast that can be made between these two, the choice of direction they confront us with, and the fact that they are both fairly (though not altogether) representative of different ways of approaching the environmental crisis. For example, in the discussion about economic growth and its relation to environmental issues (cf. Sandberg, Klockars, Wilén 2019), Deep Ecology can generally be associated with degrowth, whereas ecomodernism promotes the idea of green growth. Neither of the two supports a business-as-usual scenario for handling the environmental crisis - both Deep Ecologists and ecomodernists agree that this is not feasible. Some of the views of Deep Ecology also resonate well with views expressed in the first global assessment report on biodiversity and ecosystem services (IPBES 2019 4 ). ${ }^{5}$ For their part, ecomodernist views have a significant place

4 IPBES 2019. Summary for policymakers of the global assessment report on biodiversity and ecosystem services of the Intergovernmental Science-Policy Platform on Biodiversity and Ecosystem Services. Released May 6th 2019, available at https://www.ipbes.net/system/tdf/ spm_global_unedited_advance.pdf?file=1\&type=node\&id=35245.

5 The summary for policymakers lists "rapid human population growth, unsustainable production and consumption and associated technological development" as indirect drivers of loss in biodiversity and ecosystem functions (IPBES 2019: 15), and states: "A key component of sustainable pathways is the evolution of global financial and economic systems to build a global sustainable economy, steering away from the current, limited paradigm of economic growth" (IPBES 2019: 18-19). According to the report, a shift to a sustainable economy would "entail a shift beyond standard economic indicators such as gross domestic product to include those able to capture more holistic, long-term views of economics and quality of life" (IPBS 2019: 18-19). Degrowth models of economic welfare are mentioned explicitly (IPBS 2019: 43). 
in the EU's agenda for a European Green Deal where ideas about decoupling economic growth from environmental impact and green growth are central.

Despite its critical attitude towards the currently predominant economic growth-oriented model of development, this article adopts an optimistic view on the potential for further human development. This contrasts with the views of certain other voices in the environmental debate - for example James Lovelock, who in one of his latest books, The Revenge of Gaia: Why the Earth Is Fighting Back and How We Can Still Save Humanity (Lovelock 2006) presents apocalyptic scenarios for the future, and recommends "sustainable retreat" in place of "sustainable development", which he has lost faith in and no longer considers possible. The assumption that further human development is attainable should not be made lightly, given the unsustainability in environmental terms of our current historically high welfare levels (United Nations Development Programme 2019, 2020; O'Neill et al. 2018). In a sense we do live on borrowed time. As ecomodernists rightfully point out, however (e.g. Pinker 2019$)^{7}$, humanity has a long history of experiencing gradual improvements in living conditions by measures such as longevity and health, education and science, peace and personal safety, democracy and equal rights. While a continuation of such a history further into the future cannot be taken for granted, it is not inconceivable that even better lives and even safer living conditions are attainable in the future, if humanity collectively takes an appropriate course of action in handling the environmental crisis. On this point, if not others, this article sides with the optimistic outlook of ecomodernists.

Below I assess current human global ecology in summary terms, with an emphasis on human development and the environmental crisis. I introduce an ecosemiotic framework for the study of societal transformations and discuss political and normative aspects of what we could call transformative semiotics, including the relation between Deep Ecology and ecosemiotics. Next I outline different scenarios for the umwelt trajectory of humankind in the remaining part of the 21st century. Following up this scenario development by discussing the role of technology in relation to the (in)flexibility of different developmental paths, I introduce a distinction between complex (diverse, flexible, adaptable) and complicated (inflexible) umwelt trajectories.

6 United Nations Development Programme 2020. Human Development Index can be accessed at http://hdr.undp.org/en/content/human-development-index-hdi.

7 Pinker explicitly endorses ecomodernism. 


\section{Current global human ecology}

For some 50 years, at least since the publication of The Limits to Growth (Meadows et al. 1972; cf. also Meadows, Randers, Meadows 2002), it has been widely acknowledged that human development often conflicts with environmental sustainability. The World Commission on Environment and Development (1987) launched the notion of 'sustainable development', defined in anthropocentric terms focused on facilitating human development today without compromising the possibilities of future generations of humans. Over the last few years, connections between human development and environmental sustainability have been increasingly more recognized, e.g. in relation to the UN's sustainable development goals (United Nations 2015a). Within this framework, the international community now aims to achieve a number of interrelated social and environmental goals by 2030. In the most recent Human Development Report (United Nations Development Programme 2020), a separate chapter addresses "Climate change and inequalities in the Anthropocene" - another sign of the current efforts to see human development and ecological developments in context.

\section{Human development}

As Steven Pinker (2019) and others have documented, by many measures we are living in unparalleled times with record-high human development. For instance, while average life expectancy globally was 45.7 years in 1950 (and around 30 years in previous centuries), in 2015 it was 71.7 years; while only $12 \%$ of people were literate in $1800,86 \%$ of the adult world population was literate in 2016 ; and while a majority of humans lived in extreme poverty until the 1960-1970s, the number of people living in absolute poverty has declined rapidly since 1990 and now accounts for no more than $10 \%$ of the world population (Our world in data $\left.2020^{8}\right)$. By measures such as life expectancy, number of years in school and average income, the progress has by and large continued in most countries over the past few decades, as documented by the Human Development Index which covers years from 1990 onwards (United Nations Development Programme 2019, 2020). However, there are serious concerns about inequality (United Nations Development Programme 2019, cf. also the Inequality-adjusted Human Development Index, $\operatorname{IHDI}^{9}$ ). Furthermore, no nation on Earth currently achieves high human development without simultaneously causing considerable environ-

8 Our world in data 2020 is available at https://ourworldindata.org.

9 See http://hdr.undp.org/en/content/inequality-adjusted-human-development-index-ihdi. 
mental problems (O'Neill et al. 2018; Our world in data 2020). This implies that today's record-high human development is not environmentally sustainable, and therefore a societal transformation is required in order to safeguard human development while simultaneously achieving environmental sustainability.

The impact human development has on the environment substantially relates to three different factors: the level of economic activity per capita, the size of the human population, and the technology and practices involved (Tønnessen 2009; Steffen et al. 2011). Since year 1500, the scope of the economy (measured as annual world GDP in real terms) has increased by at least a factor of 150 (Tønnessen 2009: 120). This is in part due to increased economic activity per person, and in part due to the fact that the human population has increased from about 460 million in 1500 to about 7.6 billion in 2018 (Our world in data 2020). Economic growth as well as population growth (with more than a four-fold increase in world population) was particularly high in the 20th century, together resulting in a 19-fold increase of world GDP in 100 years (Our world in data 2020).

\section{Environmental crisis}

The enormous impact humans have on the environment and on the living conditions of non-humans today can be illustrated by Zalasiewicz et al.'s (2016) concept of the 'physical technosphere' which they define as "the summed material output of the contemporary human enterprise". Zalasiewicz et al. estimate that the current mass of the technosphere is "approximately 30 trillion tonnes $(\mathrm{Tt})^{10}$, which helps support a human biomass that, despite recent growth, is $\sim 5$ orders of magnitude smaller". In other words, for each human being currently alive, humanity has left behind material output weighing about 100,000 times as much as a human body. Zalasiewicz et al. (2016:3) refer to parts of the technosphere being "in active use" and other parts "being a material residue". The material output of humans affects the living conditions of other organisms significantly. For instance, roads and railways contribute to fragmentation of habitats, as do houses and other buildings, mines and reservoirs. Pastures and cropland direct resources to animals kept by humans at the expense of wildlife, whereas plantation forests do something similar with regard to tree species, while also affecting other flora. In geographical and geological terms, the physical technosphere can be divided into an urban, a rural, a subterranean, a marine and an aerial technosphere, with the latter involving nearly one trillion tonnes $(\mathrm{Tt})$ of $\mathrm{CO}_{2}$ among other material residue originating from human activities (Zalasiewicz et al. 2016: 9).

$101 \mathrm{Tt}$ is $10^{12}$ tonnes (i.e., $10^{15} \mathrm{~kg}$ ). 
The massive presence of human beings and our technology-mediated practices has had a significant impact on the living conditions of most organisms on Earth. In recent years, the ongoing global biodiversity crisis has been documented at length (IPBES 2019), as have the declining population numbers and continued marginalization of many wildlife species in recent decades (WWF 2018). These developments are related to the fact that human beings en masse (i.e., as a species) are now acting as an unsustainable super-predator with kill rates that are exceptionally higher than the kill rates of other predators (Darimont et al. 2015), and the fact that human beings now account for $36 \%$ of the biomass of mammals, with livestock accounting for a further $60 \%$, leaving only $4 \%$ for wild mammals (Bar-On, Phillips, Milo 2018). Scientists have documented that the Earth's biota are in the process of entering a sixth mass extinction (Ceballos et al. 2015), this time caused by humans. According to the UN panel on biodiversity and ecosystem services (IPBES 2019: 15, 18-19), overcoming biodiversity loss requires a redirection of economic systems away from growth-oriented policies towards a sustainable economy. In international politics, particular attention is being paid to global warming, with the Paris Agreement (United Nations 2015 $\mathrm{b}^{11}$ ) providing the current framework for international policy discussions and the $1,5^{\circ} \mathrm{C}$ report by the Intergovernmental Panel on Climate Change (IPCC 2018) representing the latest thought-provoking consensus report.

Scientists as well as policymakers are increasingly acknowledging that we live in an era characterized by anthropogenic environmental change, the 'Anthropocene' (Steffen et al. 2011). However, opinions differ on whether or not the Anthropocene perspective gives cause for optimism or pessimism. Ecomodernists (Asafu-Adjaye et al. 2015: 6) have suggested that humanity may have "a good, or even great, Anthropocene" ahead. In contrast, some Deep Ecologists are concerned that the Anthropocene narrative results in more hubris rather than a better understanding of the situation. Sessions (2014) thus warns of tendencies to believe in our "mastery of nature", and Oelschlaeger (2014) worries about the future of wildlife in a human-dominated Anthropocene. Other critics of ecomodernism, such as Fremaux and Barry (2019: 9), think that "we need to be particularly cautious with the Janus-faced character of the Anthropocene", which can signify scientific evidence for potential collapse, or involve "a call for more prudence, modesty, for more inclusive freedom, more respect of the natural world, for our pulling back, slowing and scaling down". The ecomodernist understanding of the Anthropocene in their view rests on an "impetus to artificialize/commodify further the planet” (Fremaux, Barry 2019: 9).

11 For the text of the agreement, see United Nations 2015b. The Paris agreement https://unfccc. int/sites/default/files/english_paris_agreement.pdf. 


\section{An ecosemiotic framework for the study of societal transformations}

After having offered a brief portrayal of the scientific and political understanding of current global human ecology, I will now establish an ecosemiotic framework for studying societal transformations in the context of the environmental crisis.

The ecosemiotic model of societal transformations I am introducing draws on umwelt theory. Any umwelt is in itself a product of an organism's modelling of its surroundings, to the effect that "the process of modelling an Umwelt turns out to be a modelling of modelling" (Kull 2010: 48). "Description of somebody's Umwelt will", in consequence, "mean the demonstration of how the organism (via its Innenwelt) maps the world, and what, for that organism, the meanings of the objects are within it" (Kull 2010: 43). This is also the case with human beings. In the context of the present article, cultural systems may also be seen as semiosic systems that are modelling systems (Kull 2010: 43-44) and enrich, coordinate and connect our individual umwelt modelling systems. ${ }^{12}$ On a more general basis, as Kull highlights, "the functional cycle", which is intimately related to the umwelt notion, involves feedback in the organism-in-its-environment system yet "is richer than the concept of feedback, because it also includes the aspect of anticipation" (Kull 2010: 47). This is related to the fact that functional cycles also concern what the organism needs and seeks out in the environment. In Kull's (2010: 48) words, they are "the general mechanisms of intentionality (interpreted in the broadest sense): the mechanisms of needs which arise during the identification of anything absent". An implication of this is that changes in the physical environment will eventually be experienced via umwelten (cf. Tønnessen 2009).

Compared to other organisms, human beings stand out by the way we can be aware of our umwelt "as an [...] objective world grasped as a whole" (Bains 2001: 159), and due to this the horizon of our anticipation also exceeds that of other species. This is why we can, for instance, participate in the environmental discourse about global human ecology while anticipating developments in the 21st century, considering the needs of humans and non-humans alike. Doing this in an informed manner presupposes that we recognize the ways in which "the environment, or nature for that matter, are resources for semiosis not only for humans, but also for other species", with "Jakob von Uexküll's functional circle" allowing "us to define such individual spheres of semiosis" (Ipsen 2006: 85).

12 Similarly, Levesque (2016: 218) refers to Tinnell's (2011: 38) observation about the modelling aspects of ecosophy (a version of Deep Ecology): "[...] we might think of ecosophy as performing a metamodeling with respect to environmental models such as the ecosystem". 
Questions concerning connections between individual humans and global human ecology are addressed in this section's subsection on scales in human ecology ${ }^{13}$ In the perspective of this article, it is clear that evidence of the human dominance of the Anthropocene is traceable in the semiosphere (understood as involving both cultural and natural sign systems; cf. Lotman 2009; Hoffmeyer 1996) through the ways in which human (cultural) sign systems exploit, regulate or in other ways have an impact on natural sign systems. With reference to Maran and Kull (2014: 41), who state that ecosemiotics addresses "the impact of maps on the mapped, on the landscapes, on the geographical systems", Olteanu et al. (2019: 569) suggest that "it is not only engineering that is responsible for this imbalance" of the Anthropocene, but also "[h] umans' representation of the environment and of themselves - their culture and (theoretical) science". This is also one of the basic premises of the present article. However, I do not agree that it is necessarily true that, unlike the notion of the Anthropocene, the notion of the "semiosphere is not negative or positive" and that "[t]o acknowledge the semiosphere is simply to acknowledge the semiotic implications of the biosphere" (Olteanu et al. 2019: 567). While the notion of the semiosphere can be used in purely descriptive terms, it would also make sense to operate with a normative notion of the semiosphere with respect to the relations between humans and non-humans where some sort of fair or sustainable balance is the measure of a "healthy" or well-functioning semiosphere (for some related discussion, see Gare 2007, 2010).

\section{Three dimensions of living nature}

My starting point for the ecosemiotic framework applied in this article is that we can think of nature as having three aspects or dimensions, namely the Umgebung, the Innenwelt, and the umwelt. These are detailed in Table 1, which shows connections between the three dimensions of living nature, the different kinds of processes each of them involves, and the corresponding levels of study, and study objects, in ecosemiotics. ${ }^{14}$

13 For a semiotic take on Earth Systems Science drawing parallels between the global notions of the Anthropocene and the semiosphere, see Olteanu et al. 2019.

14 This table contains elements from, and is a synthesis of, Table 1 in Tønnessen 2019 ("Three dimensions of living nature") and Table 2 in Tønnessen 2020 ("Adjacent levels of study in ecosemiotics with regard to related aspect of Umwelt"). 
Table 1. Three dimensions of living nature and corresponding levels of study in ecosemiotics.

\begin{tabular}{|c|c|c|c|}
\hline $\begin{array}{l}\text { Dimension of } \\
\text { living nature }\end{array}$ & Processes & Study object & Level of study \\
\hline Umgebung & $\begin{array}{l}\text { Physio-chemical } \\
\text { processes }\end{array}$ & \multirow{2}{*}{$\begin{array}{l}\text { Physiological } \\
\text { subject }\end{array}$} & \multirow{2}{*}{ Adjacent level } \\
\hline Innenwelt & $\begin{array}{c}\text { Endosemiotic sign } \\
\text { processes }\end{array}$ & & \\
\hline Umwelt & $\begin{array}{l}\text { Exosemiotic sign } \\
\text { processes }\end{array}$ & $\begin{array}{l}\text { Experiential } \\
\text { subject }\end{array}$ & Focal level \\
\hline Umgebung & $\begin{array}{l}\text { Physio-chemical } \\
\text { processes }\end{array}$ & Environment & Adjacent level \\
\hline
\end{tabular}

As we can see in the table, the dimensions of living nature do not directly correspond to the study objects in ecosemiotics. Instead, the focal level of study in ecosemiotics, related to an experiential subject as an object of study, has connections with two different dimensions of living nature, namely the Innenwelt (the subjectively construed 'inner world' of the experiential subject) and the umwelt (the subjectively experienced 'outer world' of the experiential subject) (Uexküll 1921). In the case of humans, the Innenwelt in this conception also envelops our identity, our worldview, our attitudes and our values. The umwelt and the Innenwelt are interrelated parts, or aspects, of one and the same subjective lifeworld, with the umwelt involving exosemiotic sign processes and the Innenwelt involving endosemiotic sign processes. In the latter case, it should be noted that somatic endosemiosis typically underpins Innenwelt experience without necessarily being experienced directly.

The environment as an object of study in ecosemiotics also has connections with two different dimensions of living nature, namely the umwelt of an experiential subject, and the Umgebung (the physical environment) of the same subject. While exosemiotic processes are at work in the umwelt, physio-chemical processes are in operation in the Umgebung. Another fundamental study object is the physiological subject, which, as the other study objects, has connections with two different dimensions of living nature - in this case the Innenwelt, characterized by endosemiotic sign processes, and (in the body's aspect of being physical) the Umgebung, characterized by physio-chemical processes. The complex, multifaceted nature of the study objects of ecosemiotics requires an interdisciplinary approach, addressing both semiotic and physio-chemical aspects of the subject 
matter - at least for comprehensive analysis. While the focal level of study for ecosemiotics, focused on the experiential subject, is primarily related to different kinds of semiosis, both endosemiotic and exosemiotic sign processes are ultimately grounded in the physical environment with its physio-chemical processes. ${ }^{15}$ Understanding semiosis is thus crucial for understanding processes of environmental change, but a proper understanding of non-semiosic processes is also indispensable within the same context.

\section{Scales in human ecology}

There are different ways of conceiving of scales, which have emerged as a major theoretical and methodological issue in different disciplines that are of relevance for human ecology, such as geography and ecology (for discussion, see Tønnessen 2020: 91-93). This is, among other things, due to the impossibility of addressing environmental problems "effectively in the absence of methods to relate processes of different temporal and spatial scales" (Sayre 2005: 277). A selection of scales that range from the human organism to global ecology are represented in Table $2 .{ }^{16}$ Taking the human organism as our starting point, we realize that various conceptions of the human organism and its place in nature are plausible as they are each useful in specific contexts - e.g. starting with an individual human being (Scales 1 and 2), a (human) person (Scale 3) or the human organism as a physiological subject (Scale 4). These starting points are all located at the organismic level of biological organization and associated with further scales leading up to global ecology.

15 In Table 1 this is reflected in the fact that the Umgebung appears both above the Innenwelt, and under the umwelt, indicating that what is here presented as a linear connection (UmgebungInnenwelt-umwelt-Umgebung) is in reality rather a circular connection, with the circle "biting its tail" where the physiological subject in its physio-chemical aspects in effect forms a part of the physical environment.

16 Table 2 is a reorganized version (in selection) of Table 3 in Tønnessen 2020, "Various scales in the context of global human ecology", which lists ten different scales. 
Table 2. Scales in human ecology.

\begin{tabular}{|c|c|c|c|c|}
\hline $\begin{array}{l}\text { Alternative } \\
\text { scales }\end{array}$ & $\begin{array}{l}\text { 1. Human } \\
\text { ecology scale } \\
\text { from global/ } \\
\text { human } \\
\text { perspective }\end{array}$ & $\begin{array}{l}\text { 2. Human } \\
\text { ecology scale } \\
\text { from local/ } \\
\text { ecological } \\
\text { perspective }\end{array}$ & $\begin{array}{l}\text { 3. Scale of } \\
\text { global human } \\
\text { ecology from } \\
\text { personal } \\
\text { point of view }\end{array}$ & $\begin{array}{l}\text { 4. Scale of } \\
\text { personal-to- } \\
\text { global human } \\
\text { ecology } \\
\text { from semiotic } \\
\text { point of } \\
\text { view }\end{array}$ \\
\hline $\begin{array}{l}\text { Finer } \\
\text { scales }\end{array}$ & $\begin{array}{l}\text { a. individual } \\
\text { human being } \\
\text { b. human } \\
\text { community } \\
\text { c. humanity } \\
\text { d. global } \\
\text { ecosystem }\end{array}$ & $\begin{array}{l}\text { a. individual } \\
\text { human being } \\
\text { b. local } \\
\text { ecosystem } \\
\text { c. regional } \\
\text { ecosystem } \\
\text { d. global } \\
\text { ecosystem }\end{array}$ & $\begin{array}{l}\text { a. person } \\
\text { b. household } \\
\text { c. community } \\
\text { d. landscape } \\
\text { e. ecoregion } \\
\text { f. global } \\
\text { ecosystem }\end{array}$ & $\begin{array}{l}\text { a. physiological } \\
\text { subject } \\
\text { b. experiencing } \\
\text { subject } \\
\text { c. local ecology } \\
\text { d. regional } \\
\text { ecology } \\
\text { e. global ecology }\end{array}$ \\
\hline
\end{tabular}

An individual human being can conceive of itself as being part of a human community, which is in turn part of humanity, which is in turn part of the global ecosystem (Scale 1). Here the human context (individual human being-human community-humanity) is predominant, and humans are primarily understood to be integrated into nature at the global scale. Alternatively, human beings can conceive of themselves as being part of a local ecosystem, which is in turn part of a regional ecosystem, which is in turn part of a global ecosystem (Scale 2). Here the ecological context (local-regional-global ecosystem) is predominant, and humans are primarily understood to be integrated into nature at a local scale. Furthermore, taking the human person as the starting point, persons might conceive of themselves as being part of a household (with other persons), which is in turn part of a community, which is situated within a landscape, which is part of an ecoregion, which is a part of the global ecosystem (Scale 3). Here, a communal context (person-household-community) is predominant within the larger realm of nature (landscape-ecoregion-global ecosystem), and humans are understood to be integrated into nature at the communal scale (i.e., the community is integrated into a landscape). Lastly, we might take the human organism as a physiological subject to be our starting point. As an experiencing subject, the human organism that is conscious of being a physiological subject might conceive of itself as being part of local-regional-global ecology. Here the subject's awareness of its body and its place in the ecological realm is predominant, and humans are understood to be integrated into nature firstly via their body and furthermore via their experience. 
These four scales provide four different paths from the human organism to global ecology, and all convey alternative conceptions of humans' place in, and relation to, nature, as reflected in various human practices. A set of distinct "points of view" or "perspectives" on human ecology is thus conceivable, and empirical investigations aiming at objectivity should not be strictly limited to any one of them.

\section{An ecosemiotic model of societal transformations}

In the context of this article, the notion of umwelt trajectories is applicable across scales in human ecology as presented in Table 2 above in so far as the finer scales involved concern human beings and the ways in which they relate to other creatures (i.e. non-humans). We can thus investigate the umwelt trajectory of individual human beings, or of human communities (Scale 1 or 3), or of humanity (Scale 1). In a more general sense, a specific society can be understood as a population of human beings specified in geographical or other terms as characterized by its typical umwelt features.

The definition of an umwelt trajectory (see p. 13 above) makes mention of "cultural" time (in contrast with evolutionary time) and, if read literally, implicitly applies to cultural rather than societal development. For the purpose of this article, I assume that 'culture' and 'society' (and anything cultural vs. societal) are complementary, interrelated notions, to the effect that we can refer to the sociocultural developments of a society seen as a whole. This is not meant to suggest that distinguishing cultural from societal developments cannot make sense in other contexts - or, indeed, in in-depth studies of societal transformations (e.g. by allowing for the possibility that a society is composed of people that belong to different cultures, as many modern societies are). If such a distinction were to be made, one could e.g. delimit 'societies' in geographical or administrative/institutional/legal terms, and 'cultures' in terms of typical perceptions, ideas, and action patterns/practices.

Fig. $1^{17}$ shows how different kinds of signals and causation play a role in societal development. While some instances of environmental change can be explained in terms of efficient causation without any human involvement, in other cases semiotic causation (Hoffmeyer 2008: 149) involving human agency plays a role. Moreover, whereas environmental signals are informative with regard to the condition of the current physical environment affecting our perception, umwelt

17 This figure is an adaptation and further development of Fig. 3 in Tønnessen 2019, "Threedimensional interactive semiotic model of environmental change". 
signals and Innenwelt signals mediate between our umwelt experience (our subjectively experienced 'outer world') and our Innenwelt experience (our subjectively experienced 'inner world'). The figure incorporates the three dimensions of living nature detailed in Table 1, namely the Innenwelt, the umwelt and the Umgebung. In the context of societal development, these are primarily associated with sociocultural developments (the Innenwelt), socio-ecological developments (the umwelt) and environmental change (the Umgebung).

The three-dimensional interactive semiotic model of societal transformations presented here is of a general enough nature to account for societal transformations irrespective of whether they are related to anthropogenic environmental change, so far as the societal transformations are related to the natural environment. In other words, not only can the model be applied to circumstances in which a transformed (e.g. industrialized) society triggers changes in the natural environment, and in turn is tasked with adapting to resulting changes in the natural environment (as with today's global environmental crisis) - it can also be applied to circumstances in which changes in the natural environment are not caused by human agency, but nevertheless trigger societal transformation because society is in a constant need to adapt to the natural environment in which it finds its sustenance (cf. Oelschlager 2001: 225; Levesque 2016: 533).
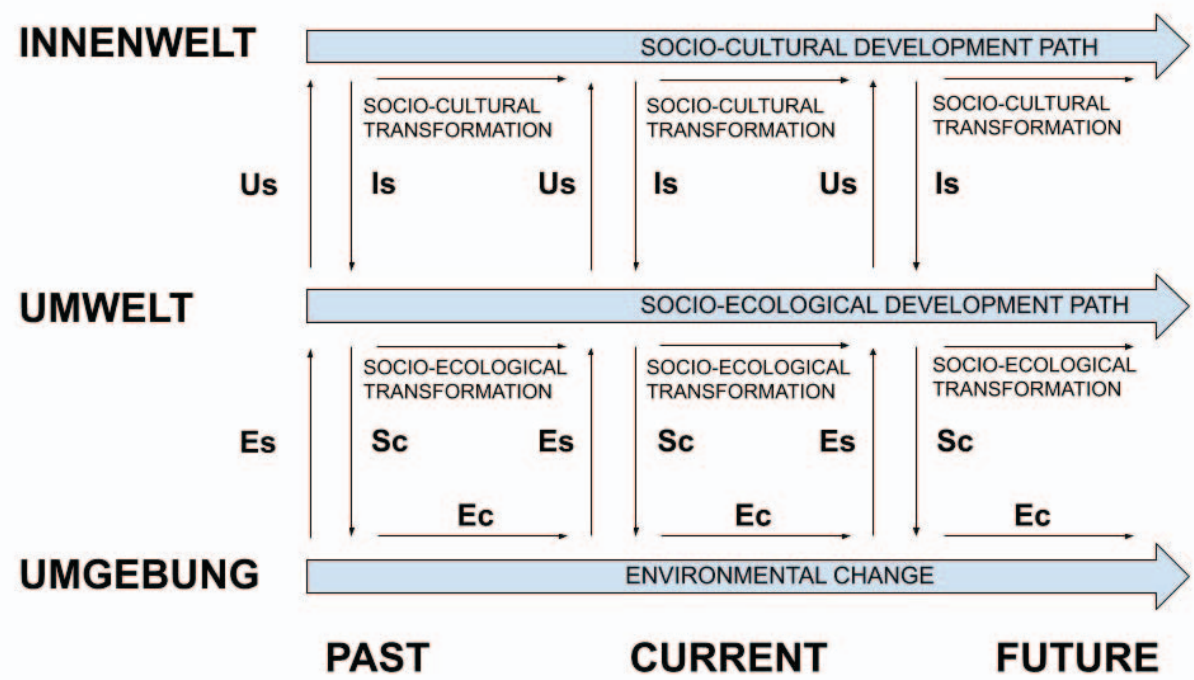

CURRENT

FUTURE

Figure 1. Three-dimensional interactive semiotic model of societal transformations. Abbreviations: Ec = efficient causation; Es = environmental signals; Is = Innenwelt signals; Sc $=$ semiotic causation; Us = umwelt signals. 
The umwelt notion is most often applied as a species-specific notion (e.g. related to typical human experience and behaviour), but it is also applicable at an intraspecies level in humans as well as non-humans. This is clearly the case in the context of cultural change. In the dimension of the Innenwelt, societal transformations can be regarded in their aspect of being socio-cultural transformations. These in turn are related to socio-ecological transformations in the dimension of the umwelt, which are in their turn related to environmental change in the dimension of the Umgebung. The model implies that socio-cultural and socio-ecological transformations are intimately related, with the former involving changes in the human Innenwelt (concerning, e.g., identities and core values) and the latter involving changes in the human umwelt (e.g. concerning worldviews and behavioural patterns). In this context, a socio-cultural transformation can be defined as a joint, long-term Innenwelt transition, i.e. "a lasting, systematic change from one typical appearance of an organism's Innenwelt to another" (Tønnessen 2019: 420) that involves the human beings making up a society. Similarly, a socio-ecological transformation can be defined as a joint, long-term umwelt transition, i.e. "a lasting, systematic change, within the life cycle of a being, considered from an ontogenetic (individual), phylogenetic (population-, species-) or cultural perspective, from one typical appearance of its Umwelt to another" (Tønnessen 2009: 49) involving the human beings constituting a society. ${ }^{18}$

While according to this model societal transformations largely amounts to joint, long-term umwelt/Innenwelt transitions, society is also presented as being on certain development paths. Specifically, socio-cultural transformations constitute a part of the socio-cultural development path of society, and socio-ecological transformations constitute a part of the socio-ecological development path of society. Just like the Innenwelt and the umwelt (and the socio-cultural and socio-ecological transformations), these development paths are also (and similarly) intimately related.

It is worth noting that any society has been going through societal transformations in the past and is likely to do so again in the future. Seen in relation to one another, the various socio-cultural transformations a society has gone (and is going) through constitute its joint Innenwelt trajectory, i.e. "the course through

\footnotetext{
18 Assuming that there can be joint umwelt/Innenwelt transitions presupposes that umwelten/ Innenwelten can be shared in some sense (e.g. within a particular culture). What I here implicitly characterize as a 'joint umwelt' by and large corresponds to what I have called a 'common-Umwelt' in Tønnessen 2003: 288-289 and defined as "a particular part of a group of umwelten, belonging to a group of subjects that have certain schemata in common. In these umwelten, the same kind of perceptual or conceptual objects appear to the subjects as the same kind of meaningful objects" (Tønnessen 2003: 289).
} 
time taken by the Innenwelt of a creature, as defined by its changing relation to itself and its own body" (Tønnessen 2019: 421). Similarly, the various socio-ecological transformations a society has gone (and is going) through constitute its joint umwelt trajectory, i.e. the course through time taken by the umwelt of people in this society as defined by their changing relations with the umwelten of other creatures (cf. Tønnessen 2014: 159, 2019: 419-420). As we can see, in our context the "socio-cultural development path" of a society is synonymous with the "Innenwelt trajectory" of the people this society is composed of, and the "socioecological development path" of the same society is synonymous with the "umwelt trajectory" of the same people.

Given the different scales in use in human ecology (cf. Table 2), the society to be studied using this three-dimensional interactive semiotic model of societal transformations can be anything from a small, local community to the global human society consisting of each and every human being on Earth. In the latter case we are concerned with a global societal transformation. In this article, we are more specifically concerned with the global societal transformation that will be required in the near future to solve the global environmental crisis of our times in a humane manner. It follows from the theoretical framework of this article that such a transformation of the global society will involve a joint, long-term Innenwelt transition and umwelt transition for human beings, and that it relates to the future development path of humankind, as manifested in the future umwelt trajectory of our species.

\section{Transformative semiotics}

In this section, I identify a few key aspects of what we could call 'transformative semiotics' in the context of solving the environmental crisis in the 21 st century while promoting human development. By 'transformative semiotics', I mean a normatively conscious form of semiotics that explicitly relates to value issues and aims to frame a perceived need for normative transformation (i.e., normative change) in semiotic terms. I start out by delineating political semiotics, then outline discussions to date about the relation between Deep Ecology and ecosemiotics, and end by identifying core normative requirements for a sustainable societal transformation. 


\section{Political semiotics}

Semiotics has often been accused of being apolitical and uncritical towards power relations. For instance, according to Bourdieu (1991: 7) semioticians tend to treat "the social world as a universe of symbolic exchanges and [...] reduce action to an act of communication", while Drechsler (2009: 77) acknowledges that semiotics has so far had little influence on political science. Drechsler (2009: 78) prefers a version of political semiotics that incorporates "a genuine semiotic approach to political matters that evolves out of semiotic thinking but is necessarily linked to politics". He points out that Jakob von Uexküll has contributed widely to political semiotics (Drechsler 2009: 89), and identifies Uexküll's book Staatsbiologie. Anatomie - Physiologie - Pathologie des Staates (Uexküll 1933[1920]) ${ }^{19}$ as "the one systematic monograph in specifically political semiotics" that he is familiar with (Drechsler (2009: 91). Unfortunately, Uexküll's own attempts to link his semiotic thinking to political thinking, as expressed in this book, do not serve as a useful starting point for a modern approach to politics (for a critical discussion, see Stella, Kleisner 2010; Tønnessen 2003: 285-286; Beever, Tønnessen 2013). While he "establishes a highly original, comprehensive model of the state, based on its economic functions, that arises from his concept of Umwelt and his biotheoretical views in an integrated way" (Drechsler 2009: 90), the views Uexküll promotes include calling for an undemocratic monarchy (Uexküll 1933[1920]: $36,67)$, discussing who qualifies as parasites with regard to the "body" of the state (Uexküll 1933[1920]: 71-76), and conceiving of the press as pathological (Uexküll 1933 [1920]: 60-61). Drechsler (2009: 91) concludes that Staatsbiologie is a "bad example, perhaps," of political semiotics, but nevertheless "proof that such a thing is possible".

This article takes a different approach to making use of Uexküll's thinking within theoretical biology in a contemporary contribution to political semiotics, by integrating umwelt theory with sociosemiotics (to which political semiotics belongs) and cultural semiotics as well as with Deep Ecology. Building political semiotics on umwelt theory in this fashion has the potential to avoid an overreliance on language and texts as much of semiotics and political theory does (cf. Drechsler 2009: 79, 80). With its connection to theoretical biology and ethology, such an approach also stands out from apolitical versions of semiotic theorizing by its natural orientation towards empirical sciences (cf. Drechsler 2009: 89). This contrasts with the "purely academic, indeed self-focused academic" discipline that semiotics in some of its manifestations appears to be, in which "the result of semiotic research does not have to be policy-relevant" (Drechsler 2009: 81).

19 First edition 1920, second edition 1933. 
Selg and Ventsel (2019: 2) defend “employing Lotman's cultural semiotics [...] for moving towards political semiotics as a key sub-discipline in both semiotics and political analysis in general", in part by explaining the relevance of Lotman's (2009) notion of the semiosphere (Selg, Ventsel 2019: 5-6). Although Selg and Ventsel apply the notion of the semiosphere in a socio-cultural rather than a biosemiotic sense, their approach to political semiotics appears to be at least partly compatible with the approach of this article.

Kobus Marais's article (2017) “'What does development stand for?' A sociosemiotic conceptualisation" is of particular relevance for the present article. While semiotics and development studies have so far not been in a theoretical dialogue, Marais (2017: 15) argues for "conceptualising development in terms of social semiotics" and "emergent semiotic response theory" (Marais 2017: 26), with semiotics providing "development scholars with the conceptual tools to include both the material and the ideal in development thinking" (Marais 2017: 15). Marais (2017: 16) observes that the increasing attention that is paid to realizing human potential in development studies gives ample room for acknowledging that semiosis, "seen as living organisms' meaning-making response to an environment, lies at the basis of human interaction". Operating with a biosemiotic framework, he acknowledges that "societies and cultures are systems of meaning" (Marais 2017: 18) whose "development trajectory" relies on "the ability of living organisms [in this case human beings] to interact with and respond to whichever environment they found themselves born into" (Marais 2017: 21). With its reliance on sociosemiotics combined with biosemiotics, Marais's approach to development studies as reiterated here can clearly be reconciled with the perspective on human ecology adopted in this article.

\section{Deep Ecology and ecosemiotics}

The core views of Deep Ecology are summarized in the Deep Ecology platform, first developed by Arne Næss and George Sessions (the following version derives from Næss 1993: 197):

(1) The well-being and flourishing of human and non-human life on Earth have value in themselves (synonyms: intrinsic value, inherent worth). These values are independent of the usefulness of the non-human world for human purposes. 
(2) Richness and diversity of life forms contribute to the realization of these values and are also values in themselves.

(3) Humans have no right to reduce this richness and diversity except to satisfy vital needs.

(4) The flourishing of human life and cultures is compatible with a substantially smaller human population. The flourishing of non-human life requires a smaller human population.

(5) Present interference with the non-human world is excessive, and the situation is rapidly worsening.

(6) Policies must therefore be changed. These policies affect basic economic, technological, and ideological structures. The resulting state of affairs will be deeply different from the present.

(7) The ideological change will be mainly that of appreciating life quality (dwelling in situations of inherent value) rather than adhering to an increasingly higher standard of living. There will be a profound awareness of the difference between bigness and greatness.

(8) Those who subscribe to the foregoing points have an obligation directly or indirectly to try to implement the necessary changes.

An Uexküllian reading of the Deep Ecology platform is provided in Tønnessen 2003. There is a direct link between Uexküll's work and the work of Næss as Næss made use of and discussed Uexküll's umwelt theory in his doctoral thesis (Næss 1936, particularly pp. 64-70). To my knowledge, Næss never referred to Uexküll in writing in the context of Deep Ecology. As mentioned in Kull (2011: 69), however, Næss participated in a seminar held in Tartu in 1998 where ecosemiotics was also discussed.

Kull, Kotov and Keskpaik (2004: 26) introduce the "Semiotic fundamentals of Deep Ecology" in a form that resembles the Deep Ecology Platform, starting out with the claim that "[a]ll life is semiosic" and acknowledge that "diversity is the fundamental characteristic of life", with "[q]ualitative diversity" being "a basic value" that "is more fundamental than any measurable (quantitative) value". The text is primarily concerned with the relation between culture and nature, and establishes that "[c]ulture is a subsystem of [the] biosphere and like any other subsystem of [the] biosphere, it is functionally related to the total web of semiotic interrelations in [the] biosphere", although some cultural sign systems "are autonomous of other sign processes in the biosphere" (Kull, Kotov, Keskpaik 2004: 26) (these are emergent behaviours). The culture/nature distinction is itself a cultural 
construct, and thus amendable, given cultural change. ${ }^{20}$ Specifically, the ecosemiotic assumption "that [the] semiosphere coincides with the biosphere leads to a cultural reconceptualisation and transformation of the relations between culture and its natural environment" (Kull, Kotov, Keskpaik 2004: 26).

Kull (2011: 69) presents an approach to human ecology "as a development and reformulation of deep ecology principles on a semiotic basis" in the form of a list (in three versions) of the "Ecosemiotic principles of Deep Ecology". ${ }^{21}$ Selfawareness enables the human being "to learn how to act without transforming the environment and without using violence" despite its "unprecedented capacity for violence, for affecting other species and its own environment" (Kull 2011: 70). ${ }^{22}$ Modern culture has "increased uniformity" in a way that has led to "a corresponding reduction in diversity". Kull's stated goal is "the preservation (non-alteration) of the world" (Kull 2011: 71) that should be pursued by a 'non-cumulative culture' which should be "a highly diverse, in-equilibrium, culture based on steady-state economy and recycling", presupposing "a decrease in globalisation" (Kull 2011: 73) and maintenance of cultural and biological diversity. "Although environmental problems are varied," Kull (2011: 74) stresses that "it generally holds that if diversity is preserved, most other problems are avoided". Even though humans can legitimately change the environment to some extent, as all species do, "it should not be irreversibly transformed, because it is then that environmental problems appear" (Kull 2011: 74).

Levesque (2016) compares the ecosophies of Arne Næss and Félix Guattari (2013) and the relation between ecosophy and semiotics. An 'ecosophy' is a term that was introduced by Næss (1989 - the Norwegian editions appeared in the 1970s) to denote a philosophy of 'ecological wisdom'. In Levesque's (2016: 512) words, "an ecosophy is a philosophical worldview or a system inspired by our living conditions in the ecosphere". Levesque agrees with Tinnell (2011:37) saying that "Næss [...] does not think through the semiotic implications of the word as fully

20 In the same vein, Ipsen (2006: 83) argues that "the human agency in conceptualising the Umwelt necessarily transforms what we usually call "nature" into so-called "culture"', to the effect that "any environmental perception is at once conceived of in cultural terms". This also goes for any 'nature concepts', which are "part of culture indeed, as all of our concepts" (Ipsen 2006: 84).

21 According to Kull (2011: 74), the semiotic foundation of human ecology in general and Deep Ecology in particular points to the need for further semiotic work within e.g. moral philosophy, philosophy of science, cultural theory, economics and education.

22 It should be noted that Gandhi's teachings of nonviolence was one of Næss' major sources of inspiration. Altogether Næss wrote four books on Gandhi and his doctrine of nonviolence, and he also emphasized that nonviolent methods should be applied by the environmental movement. 
as Guattari does" but claims that "many aspects of his thoughts on Deep Ecology are inherently semiotic" nevertheless (Levesque 2016: 526). For instance, Levesque points out that both ecology and semiotics are concerned with relations. He also stresses the intermingling of ontological beliefs, ethical values, and political attitudes that the ecosophy of Næss addresses and aims to influence by relating them to semiotic processes, stating that " $\mathrm{t}] \mathrm{h}$ e ecosphere is at once a semiosphere, where political ideas are communicated, and an axiological territory, where dominance over normative value apparatuses is negotiated" (Levesque 2016: 528). In the words of Næss (1989: 74) himself, "our opinions as to what is or ought to be done are highly dependent upon our hypotheses as to how the world is organized. Applied to ecological relationships, this implies that our norms are dependent upon our beliefs regarding the interdependency relations within the biosphere". In this article, this understanding is reflected in the portrayal of the dynamical relation between socio-cultural and socio-ecological transformations (cf. Fig. 1).

Levesque rightly emphasizes the practical aspects of Næss' ecosophy and any other ecosophy. In Næss' conception, ecosophy as an environmental philosophy is "more than a mere abstract system of thought", since "it calls for a radical change in views and beliefs" (Levesque 2016: 512) and critically assesses our practices and behaviour. This is also why Næss described and wanted to inspire a Deep Ecological movement. "Adopting an ecosophical worldview should help induce new organizational models at the species level (taken as the widest cultural system possible), thus instilling a lifestyle that is coherent with the ethical commitment Deep Ecology prescribes" (Levesque 2016: 530). The practical objective of Deep Ecology as an environmental philosophy, Levesque (2016: 536) concludes, "helps us understand why semiotics cannot be reduced to modelling, for models and praxis are coextensive". This pinpoints the relevance of a semiotic ethic.

Max Oelschlaeger has written about both ecosemiotics and Deep Ecology, but to my knowledge not in one and the same paper. Oelschlaeger (2001) discusses how far ecosemiotics can contribute to the "sustainability transition". Concerning the need for cultural change, he states that the currently dominant cultural code "overdetermines the future, thereby perpetuating ecologically untenable cultural forms" (Oelschlaeger 2001: 219). "Ecosemiotic inquiry", in his view, "frames cultural codes as these shape and reproduce the ongoing stream of individual and societal choices that shape distinctively human existence in a larger context of biophysical realities" (Oelschlaeger 2001: 219).

In another article, Oelschlaeger (2014: 237) raises the question of what Deep Ecology will amount to in the 21 st century. Will it remain "a somewhat esoteric philosophy/world view shared among a relatively small population of academics and activists", or serve "as a strange attractor perturbing a complex, 
far-from-equilibrium cultural system in ways that might increase the potential for sustainability" (Oelschlaeger 2014: 237), thus proving to have "the catalytic power to transform the human endeavor" (Oelschlaeger 2014: 246)? Only time can tell.

\section{Normative requirements for a sustainable societal transformation}

In light of the treatment of political semiotics and the relation between Deep Ecology and ecosemiotics, a few observations on transformative semiotics can now be made. Firstly, political semiotics qualifies as transformative semiotics in so far as it involves an agenda for normative transformation. Secondly, conceptually it is clear that political semiotics is not the only possible form of transformative semiotics - for example, biosemiotics can be conceived of as involving an agenda for normative transformation with regards to the scientific norms of biology (and to some extent science at large). And thirdly, by relating to human ecology, ecosemiotics constitutes a form of transformative semiotics in so far as human ecology is approached critically in a political, ethical and/or another normative context. This is no less the case if ecosemiotics is integrated with Deep Ecology, which clearly involves an agenda for normative transformation.

A key difference between Deep Ecology and ecomodernism is that whereas Deep Ecology is explicitly non-anthropocentric, ecomodernism appears to be predominantly anthropocentric (i.e., concerned with human interests only). Among the few mentions of values in An Ecomodernist Manifesto (Asafu-Adjaye et al. 2015), values related to non-humans are mentioned only once, when it is stated that "[e]xplicit efforts to preserve landscapes for their non-utilitarian value are inevitably anthropogenic choices" (Asafu-Adjaye et al. 2015: 26). The impression that is given is that humans are the only valuing agency on the planet. It is also worth noting that the mention relates to the value of landscapes, while nothing is stated about the intrinsic value, if any, of individual organisms. A reasonable interpretation of the concerns about wildlife that are expressed in An Ecomodernist Manifesto is that wildlife, and nature, is first of all considered as humanity's basis for existence, thus having only instrumental value [cf. the acknowledgement early on in the manifesto that "humans are completely dependent on the living biosphere" (Asafu-Adjaye et al 2015: 9)]. In light of the present article, this implies that unlike Deep Ecology, which is concerned with both human development and the prospects and living conditions for non-humans due to their intrinsic value, ecomodernism is primarily concerned with human development only. This in turn means that Deep Ecologists and ecomodernists have entirely different conceptions of what solving the environmental crisis by accomplishing a sustainable 
societal transformation is about - and whom it affects. In an ecomodernist outlook, solving the environmental crisis is crucial because it is necessary for promoting human development. In this sense it is an instrumental problem. In a Deep Ecological outlook, however, solving the environmental crisis is important in its own right - and promoting human development is part of a larger undertaking of promoting the "well-being and flourishing of human and non-human life on Earth" (Næss 1993: 197).

While ecomodernists and Deep Ecologists have contrasting, competing views on sustainability, it is worth recalling that the status quo is deemed to be unsustainable by both scientists and policy makers, and thus a simple prolongation of current practices and behaviours is not considered realistic (United Nations 2015a, IPCC 2018, IPBES 2019). The question is therefore not whether the state of affairs will change, but how it will change - and what sort of societal transformations will happen later in this century and beyond. ${ }^{23}$

The disagreements between Deep Ecologists and ecomodernists succinctly illustrate that there is no general agreement about the normative requirements for what constitutes a sustainable societal transformation. However, the premises of this article give some directions, at least for the approach taken here: a truly sustainable societal transformation must include safeguarding future living conditions for humans (cf. United Nations Development Programme 2019, 2020, which emphasizes longevity as a proxy for health; education; and sufficient income), and safeguarding future living conditions for non-humans. An ethical framework for the latter is provided in biosemiotic ethics as developed in Beever, Tønnessen 2017 and Tønnessen, Beever 2014. Given the emphasis in biosemiotic ethics on the semiotic agency of humans and non-humans, one could add that a further, implicit normative requirement is to facilitate genuine autonomy for both non-humans and humans (cf. Mill 2001 with regard to the value of liberty in lifestyle choices for humans).

As Crist (2015: 245) observes, in the ecomodernist manifesto human freedom is considered a core value. In consequence, she writes, the development of the global population size should in this view not be politicized, as that could "challenge people's reproductive behavior or their current cultural norms", therefore "global population size is something that happens not an issue we deliberately and concertedly do something about" (Crist 2015: 246). ${ }^{24}$ A key goal of the manifesto

23 In this sense the 'status quo' is just as utopian as Deep Ecology or ecomodernism - or even more.

24 In defense of ecomodernism, one should note that Asafu-Adjaye et al. (2015: 11-12) write that world population may peak this century and then start declining. Rather than defending further population growth, ecomodernists hold that the population issue is on its course to becoming solved. 
is to make it possible "for all people to enjoy the social and material freedoms that modernity offers" (Crist 2015: 250). However, there is no criticism or acknowledgement in the manifesto of the fact that under current human ecology, "so many beings (wild and domestic) are deprived of the freedom to move, enjoy life, or even exist" - apparently because the ecomodernist understanding is "that there exist no claims to freedom within the nonhuman realm that command limits to human expansionism" (Crist 2015: 251). Freedom, in this view, is a human prerogative. As Crist (2015: 252) observes, the "problem does not lie with the ideal of freedom, but with limiting that ideal to humanity", which in practice entails that "human freedom becomes easily founded on the demolition of nonhuman freedom", which "is exactly the predicament we are in".

"What if we took on board the aspiration to human freedom", Crist (2015: 252) asks, "but broadened it into a universal ideal. Our intent would become creating an ecological civilization which honored the freedom of all - nonhuman and human." This is in a sense exactly what Deep Ecology aims to do. As Crist notes, this would require us to think anew about and in some cases restricting some of our distinctly human freedoms, e.g. with regard to "how many of us there are, how we organize our economic relations, and what proportion of land and seas we occupy and use". Crist (2015: 254) befittingly concludes that "genuine human freedom cannot be achieved at the expense of the freedom of the whole", for one thing because basing our own freedom on the demolition of the freedom of others undermines "the dignity of the human that humanism holds so dear".

Rethinking human freedoms might also require thinking anew about democratic institutions and international relations. In the context of the increasing acknowledgement of there being an ecological crisis of planetary scale, Mert (2019: 128) remarks that "there is no stable political system in place to address these challenges at the corresponding scale of governance". Change is required, as the reality of the Anthropocene "forces us to think innovatively about democracy, to deconstruct certain traditions and learn from peripheral and marginalized knowledge-bases and the nonhuman environment" (Mert 2019: 144). A Deep-Ecological perspective will also imply that we think about justice not just in terms of intra-human justice (i.e. justice between humans, generational justice included), but also in terms of inter-species justice. This requires us to become sensitive to power relations between humans and non-humans as well, given that human dominance over non-humans is a key characteristic of the Anthropocene.

Some might regard a Deep Ecological society, or an ecomodernist society (or both) as a sort of utopian fantasy. ${ }^{25}$ This justifies a brief treatment of the role

25 Here it is worth keeping in mind that one person's utopia can be another person's dystopia. 
of utopias within political semiotics. "We cannot advance if we do not think in utopias," Drechsler (2009: 80) states. In terms of normativity, we can think about utopias as societies with norms that are in some respects radically different from those of the current society. In the words of Ernst Cassirer (1944: 62):

The great mission of the Utopia is to make room for the possible as opposed to a passive acquiescence in the present actual state of affairs. It is symbolic thought which overcomes the natural inertia of man and endows him with a new ability, the ability constantly to reshape his human universe.

If politics is the art of the possible, as is often claimed, then utopias could be described as imagined future societies that are outlined with the motivation of enhancing our capacity for thinking about what is possible in terms of societal change. As practical political tools, however, utopias are ambivalent, in that they depend on combining utopian aspirations, aiming at a future society in which "state of affairs will be deeply different from the present" (Næss 1993: 197), with a degree of realism regarding the anticipated political action towards the realization of such a society. Without a realistic hope of inspiring political action and influencing political thinking, any utopia becomes irrelevant for current political discussions. In this sense, the measure of a utopia's performance as a political idea is the degree to which it succeeds in influencing current debates in accordance with its basic aspirations, thus setting the political discourse on a course towards the promised utopia.

\section{Umwelt scenarios for global human ecology in the 21 st century}

The notion of umwelt scenarios was developed in Tønnessen 2019. As in the field of scenario planning in general, umwelt scenarios are meant to represent alternative plausible futures (Tønnessen 2019: 424-425). Rather than predicting future developments, they provide us with ideas about different developmental paths or options we are faced with in contemporary times. In relation to umwelt trajectories (Tønnessen 2014), umwelt scenarios can be seen as different future paths that historically grounded contemporary umwelt trajectories might plausibly take.

With millions of species on planet Earth, many of which are not yet thoroughly researched, how can we possibly develop umwelt scenarios for global ecological developments? Current ecology is dominated by human ecology, i.e. ecology in which human agency is a decisive factor. This implies that by describing the future development of the human umwelt, we implicitly describe some of the future 
conditions for millions of other species as well. The scenario development in this article will therefore be focused on the human umwelt.

The starting point for any ecologically relevant societal transformation lies in the current socio-ecological circumstances. In Fig. 2, we can see an illustration of a number of fundamental relations in human ecology. These are fundamental in the sense that they "outlast" societal transformations, and in this sense they are timeless. However, any given societal transformation with a socio-ecological aspect will tend to be reflected in changes in some of these fundamental relations. The fundamental relations are depicted as 'phenomenal fields' (cf. Brock 1939, discussed and further developed in Tønnessen 2011: 41-45), with each circle representing an umwelt divided into four fields, namely that of the partner, that of the medium, that of the enemy, and that of food. These four functional fields correspond to what according to Uexküll is the four main categories of functional cycles (cf. Uexküll 1928: 101).

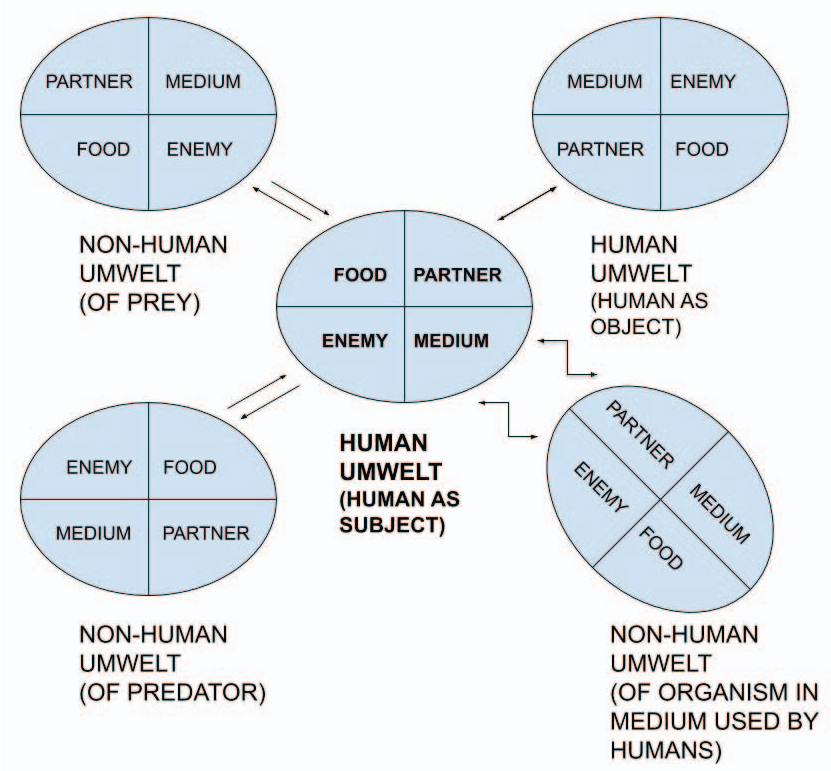

Figure 2. Fundamental relations in human ecology. Parallel straight arrows pointing in opposite directions indicate a contrapuntal relation (food-enemy relation, typically a predator-prey relation). Straight arrows pointing in opposite directions indicate a mutual relation (partner-partner relation, typically a sexual relation). Elbow connectors indicate possible relations between individuals or groups of humans and non-human umwelt creatures related to our medium use (land use, use of lakes, rivers and oceans, etc.), where the humans involved might (in a wide, functional sense) be perceived as enemies or as partners by the non-human umwelt creature. 
The scenarios presented in this section are organized in line with the categorization of phenomenal fields as presented in Fig. 2. Specifically, the scenarios are concerned with the ways in which humans relate (in terms of perception and action) to the medium, as well as to food and other resources, and with the ways in which humans engage in partner relations, and in enemy relations. Partner relations are here understood as relating to sexual partners and reproduction, i.e. human-human relations in the context of population issues. Taken as a whole, the scenario development in effect implies describing anticipated environmental change (in the human Umgebung) in terms of how it is experienced by human beings and by the non-humans we encounter or have an impact on (in human and non-human umwelten and Innenwelten). There is not much room here for dwelling on the ways in which the basic biological functions of the human umwelt (and their respective phenomenal fields) are interrelated. Still, it should be noted that they are - e.g. that our medium use is to a large extent shaped by our food requirements and preferences.

This article will not address questions about future changes in governance, democratic institutions, etc. Conscious changes related to behaviour and practices may in principle be initiated on different scales of human ecology, ranging from the individual (personal lifestyles or action) via communities to the global scale. To outline different plausible futures, I will contrast Deep Ecology with ecomodernism as well as with a business-as-usual scenario for the human umwelt in the 21st century, with the main focus being on the diverging scenarios rather than the business-as-usual scenario. Each of the different resulting umwelt trajectories for the human species will be associated with different future human ecologies. As for plausibility, the assessment of the three kinds of scenarios as plausible rests on the assumption that they are all reconcilable with a continued existence of human civilizations on Earth (at least within the timeframe of the 21st century). In this context, it is far from given that a business-as-usual scenario is any more plausible than diverging scenarios. The general agreement globally that the current practices are unsustainable in many aspects has two implications: first, that a business-as-usual scenario cannot be understood as a mere continuation of the current practices in the future, since this is not realistic in all cases; and second, that a business-as-usual scenario might involve future change in some of these practices. However, these must lie within the realm of possibilities that can be expected given the past developments. The diverging ecomodernist and Deep Ecologist scenarios can involve more radical breaks with the past.

Before moving on to the umwelt scenarios related to the four different phenomenal fields, I summarize some of the key differences between Deep Ecology and ecomodernism. While Deep Ecologists such as Arne Næss $(1973,1989)$ 
believe that economic growth and overconsumption are key causes of the environmental crisis and favour simpler lives in material terms, ecomodernists see economic growth as a matter of fact (Asafu-Adjaye et al. 2015: 22) and have a positive, optimistic attitude to the "growing social, economic, and technological powers" of humans (Asafu-Adjaye et al. 2015: 6). While affirming "one long-standing environmental ideal, that humanity must shrink its impacts on the environment to make more room for nature," ecomodernists "reject another, that human societies must harmonize with nature to avoid economic and ecological collapse" (AsafuAdjaye et al. 2015: 6). Instead, they favour "decoupling human development from environmental impacts" (Asafu-Adjaye et al. 2015: 7) and believe that this is, in fact, possible. To ecomodernists, life in cities is emblematic of modern progress: "Cities, as people know them today, could not exist without radical changes in farming. In contrast, modernization is not possible in a subsistence agrarian economy" (Asafu-Adjaye et al. 2015: 13), which would use much more land per person. They therefore call for high-tech developments, such as reliance on and further development of nuclear energy. This is in stark contrast with the leanings of Deep Ecology, which is rather in line with Arne Næss' slogan of leading a "rich life with simple means".

As for future developments, Næss (1995[1992]: 465-466) outlines five different scenarios for paths towards sustainability globally, with four of the scenarios involving ecological catastrophes before a fundamentally new course is taken. The fifth scenario entails a development in which there is a gradually "increasing influence of the Deep Ecological attitude, and a slow decrease of the sum total of unsustainability" (Næss 1995[1992]: 466]). Næss (1995[1992]: 466) calls this "the rational scenario: one that guarantees the least strenuous path toward sustainability by the year $2101 "$.

\section{Scenarios for human medium use}

Business-as usual-scenario. Humans will utilize an even larger part of the land and oceans of the Earth than today for human purposes. This will lead to continued marginalization of wildlife (IPBES 2019). From an umwelt perspective, the most extensive landscape changes will not necessarily be experienced directly by most humans, due to further urbanization. The impact on animals' experience and living conditions will be significant. 
Ecomodernist scenario. An Ecomodernist Manifesto calls for a "deeper emotional connection" to landscapes, and for demanding "more wild nature for aesthetic and spiritual reasons" (Asafu-Adjaye et al. 2015: 25; cf. also Ellis, Mehrabi 2019 in which the idea of reserving half of Earth for wilderness is assessed by Erle Ellis, one of the co-authors of the manifesto). Conservation is promoted e.g. by applying more intensive agricultural practices, which will leave more land for wildlife (Asafu-Adjaye et al. 2015: 27), and by stimulating further urbanization. However, the manifesto (Asafu-Adjaye et al. 2015: 20) also appears to state support for Bioenergy with Carbon Capture and Storage (BECCS - see discussion in the section "Technology and sustainability"), which has been widely criticized for requiring a lot of land. This may work against the ecomodernist goal of securing more land for wildlife. In sum, it is reasonable to assume that ecomodernist policies will result in more intensive and less extensive land use, resulting in reserving more land than today for wildlife, even though some land areas will be utilized in new ways for the purpose of mitigating climate change. From an umwelt perspective, this will involve an intensification of industrialized agricultural and forestry practices and thus fewer people experiencing life in rural settings. Most people will live in urban settings and will not experience any of this directly. Wildlife in different areas will be affected by changing human agendas.

Deep Ecology scenario. The idea of leaving half of Earth for wilderness has also been defended with reference to ecocentrism. Kopnina et al. (2018: 146) stress that conceiving of conservation as "a quest to save abundant life on earth, and not merely for the sake of human welfare," requires us to acknowledge "the intrinsic value of nature". Deep Ecologists generally emphasize the importance of conservation of land (Næss 1989; Sessions 2014; Oelschlaeger 2014), and tend to favour less intensive as well as less extensive land use. Deep Ecologist policies would clearly leave more room for wildlife, both on land and in aquatic environments. From an umwelt perspective, this would mean improved living conditions for most species. A Deep Ecology approach to land use would also mean that humans would spend more time in outdoor and wilderness settings, to the effect that people would be "closer" to nature and have more nature experiences. As for mitigating climate change, so-called "natural climate solutions" are a good fit with the Deep Ecologist mindset. Griscom et al. (2017: 11645) identify "20 conservation, restoration, and/ or improved land management actions that increase carbon storage and/or avoid greenhouse gas emissions across global forests, wetlands, grasslands, and agricultural lands". The fact that natural climate solutions can provide a substantial portion of the climate mitigation needed to stabilize global warming to below $2^{\circ} \mathrm{C}$, while at the same time "improving soil productivity, cleaning our air and 
water, and maintaining biodiversity" (Griscom et al. 2017: 11645) make them a win-win solution that will not cause other environmental or social problems. ${ }^{26}$

\section{Scenarios for human food consumption}

Business-as-usual scenario. A growing world population will require increased food production, and higher incomes will result in a particularly high increase in meat consumption (EAT-Lancet Commission 201927). From an umwelt perspective, current trends point towards fewer farmers and thus fewer people experiencing animal husbandry, and more intensive production and thus more livestock experiencing in-door environments only (cf. FAO 2006). As for hunting and fishing of wildlife, several species risk being overexploited (Darimont et al. 2015).

Ecomodernist scenario. While favouring technology-based intensive agriculture, Asafu-Adjaye et al. (2015: 14) also indicate that "demand for many material goods may be saturating as societies grow wealthier. Meat consumption, for instance, has peaked in many wealthy nations and has shifted away from beef toward protein sources that are less land intensive". Ecomodernist policies will focus on satisfying the demand for food and apply modern technology to optimize food production. "With proper management," in this scenario (Asafu-Adjaye et al. 2015: 10), "humans are at no risk of lacking sufficient agricultural land for food". From an umwelt perspective, ecomodernist policies are likely to safeguard human welfare with regard to the need for decent food and nutrition. The anthropocentric inclinations of ecomodernism might, however, potentially mean that the implications for non-humans will be worse. Optimizing food production aiming solely or predominantly at the satisfaction of human needs and wants can affect the living conditions of animals kept for their meat value or other animal products negatively. ${ }^{28}$

26 In a Deep Ecology scenario, land conservation and management can fruitfully be informed by ecosemiotic studies on landscapes that explore how meanings are generated for humans dwelling in a landscape, but also go beyond anthropocentric perspectives by focusing on the functions landscapes have for non-humans and their experience (Lindström, Kull, Palang 2011; Ljungberg 2001). Connections may also be made between umwelt theory and landscape ethics (Gens 2013; cf. also Potter 2016).

27 EAT-Lancet Commission 2019. Healthy diets from sustainable food systems. Food planet health.Availableat:https://eatforum.org/content/uploads/2019/04/EAT-Lancet_Commission_ Summary_Report.pdf.

28 It might be symptomatic for ecomodernist policies that while 'wildlife' is mentioned twice in the manifesto, 'animals' are not mentioned (nor is 'organism') - though 'animal feed' is mentioned in the context of food production (Asafu-Adjaye et al. 2015: 13). 
Deep Ecology scenario. A development in line with Deep Ecology principles requires that human kill rates for several prey and fish species should be reduced significantly. ${ }^{29}$ This would make the human species less of an unsustainable superpredator (cf. Darimont et al. 2015), and would be reflected in changed perceptions and behaviours in human umwelten, as well as in the umwelten of affected non-humans. Deep Ecologist policies are furthermore a good match with a "planetary health diet" that is both healthy and environmentally sustainable, as recommended by the EAT-Lancet Commission (EAT-Lancet Commission 2019; for full report see Willett et al. 2019). Such a diet will be more plant-based, at least doubling the consumption of nuts, fruits, and vegetables, while reducing the consumption of red meat by more than half by 2050 (EAT-Lancet Commission 2019). Reduced consumption of meat and other animal products leads to less land use (and thus more space for wildlife, and for organic farming), less climate gas emissions, improved human health, and plausibly better welfare in animal husbandry.

\section{Scenarios for human partner relations}

Business-as-usual scenario. The world population is likely to continue increasing, but at a slower pace, until it most likely stabilizes around the end of the 21 st century (UN DESA 2004), depending on developments in Africa (Our world in data 2020). From an umwelt perspective, this will typically involve longer lives, smaller families, and changing social roles for humans, and further marginalization of non-humans.

Ecomodernist scenario. In an ecomodernist outlook, the development of the world population is not regarded as a key challenge in the context of solving the environmental crisis (Asafu-Adjaye et al. 2015: 9, 11). It is stressed that drivers of population growth such as longer life expectancy and lower infant mortality are beneficial to human welfare (Asafu-Adjaye et al. 2015: 11). From an umwelt perspective, this implies that ecomodernist policies will favour family and sexual relations that support human welfare without operating with any overriding concern for the ecological implications of human population issues.

29 In a wide, functional sense, livestock can be regarded as the predominant modern "prey" for humans, even though they are not strictly speaking hunted (though they are typically kept captive and eventually slaughtered) and do not necessarily perceive of human beings as enemies. 
Deep Ecology scenario. UN scenarios for the size of the world population at the end of this century and for the next two centuries show that world population could realistically decline, stabilize, or continue increasing in the long run (UN DESA 2004). The diverging scenarios build on moderately different assumptions about the future fertility rate (average number of children per woman), ranging from 1.8 to 2.2. This demonstrates that a conscious, long-term population decline as advocated by Deep Ecologists (Næss 1989, 1993; cf. also Tønnessen 2008) can be achieved with humane means. A society with long-term population decline will be characterized by small families, high median age and a large proportion of older people compared to younger people. From an umwelt perspective, this would give room for allocating more land, water and resources to wildlife, thus improving the living conditions of (wild) non-humans.

\section{Scenarios for human enemy relations}

Business-as-usual scenario. A continuation of excessive kill rates (Darimont et al. 2015) for animals that are not utilized for meat or other products will lead to continued and possibly accelerating marginalization of wildlife, which will be further endangered due to a prolongment of extensive land and resource utilization (IPBES 2019). The motivation for regarding animals as enemies seldom refers to threats posed to human life and health, since most large carnivores and megafauna have been decimated already. More often, animals are now regarded with enmity because they are considered a nuisance in light of other human interests, including land development, agricultural production, and a desire for controlled environments. From an umwelt perspective, most humans will not experience this directly, due to continued urbanization. The animals involved, however, will.

Ecomodernist scenario. An Ecomodernist Manifesto acknowledges that "human flourishing has taken a serious toll on [...] wildlife", with many animal populations declining rapidly the last 40 years (Asafu-Adjaye et al. 2015: 9). While enmity towards wildlife is not addressed directly, the manifesto supports re-wilding (Asafu-Adjaye et al. 2015: 15) and states that even though "future generations could survive and prosper materially on a planet with much less biodiversity and wild nature", this nevertheless "is not a world we want" (Asafu-Adjaye et al. 2015: 25). In an ecomodernist understanding all conservation efforts emerge as "fundamentally anthropogenic" (Asafu-Adjaye et al. 2015: 26) and related to "human preferences" (Asafu-Adjaye et al. 2015: 27). These views would result in ecomodernist policies that strive towards preserving wildlife, justified by anthropocentric 
reasons such as satisfying humans' aesthetic and spiritual needs (cf. Asafu-Adjaye et al. 2015: 25). From an umwelt perspective, this will imply sustained conservation efforts that give satisfaction to many humans who care about wildlife, which will improve the living conditions of several wild animal species.

Deep Ecology scenario. With its emphasis on acknowledging the intrinsic value of non-human life as well as the recognition that humans "have no right to reduce" natural richness and diversity "except to satisfy vital needs" (Næss 1993: 197), Deep Ecology favours conservation efforts motivated by ecocentric reasoning. However, anthropocentric reasoning plays a role in that human needs are considered and given that the quality of life for humans should also be prioritized (Næss 1993: 197). This will result in respect for and co-existence with wildlife rather than a human attitude of enmity. From an umwelt perspective, this will result in a considerable reduction in human persecution of large carnivores, and a change in the functional tone of predators in the human umwelt from "an enemy" towards a more amiable relationship, such as a (perhaps one-sided) social relationship (cf. Tønnessen 2016). Due to a long history of persecution by humans, however, shy predators may still continue for a good while to be fearful of humans.

In the next section, I will explore the differences between these various plausible futures by looking into the difference between flexible and inflexible development paths, and an orientation towards high-tech $v s$. low-tech developments.

\section{Technology and sustainability}

In the following, the ecosemiotic analysis of the envisioned societal transformations in the context of the environmental crisis is focused on different views on technology, which is a key matter of dispute between ecomodernism and Deep Ecology. Two underlying questions are how technology affects our umwelt experience and how technological developments affect our range of lifestyle choices in the long run. High-tech developments may lock us into inflexible development paths, which reduces the behavioural complexity of humankind, while a more low-tech orientation might allow for a more flexible development path, which would safeguard behavioural complexity for the future.

Ecomodernist thinkers see technology as central to solving environmental problems and promoting human development, and generally have a positive attitude to technological innovations. This is expressed already in the second paragraph of An Ecomodernist Manifesto: 
As scholars, scientists, campaigners, and citizens, we write with the conviction that knowledge and technology, applied with wisdom, might allow for a good, or even great, Anthropocene. A good Anthropocene demands that humans use their growing social, economic, and technological powers to make life better for people, stabilize the climate, and protect the natural world. (Asafu-Adjaye et al. 2015: 6)

Ecomodernists believe that technology plays a key role "in reducing humanity's dependence on nature" (Asafu-Adjaye et al. 2015: 9), and think a "[d] ecoupling of human welfare from environmental impacts" (Asafu-Adjaye et al. 2015: 29) is possible which "will require a sustained commitment to technological progress" (AsafuAdjaye et al. 2015: 29). On related themes, see Stoknes, Rockström 2018 on "green growth" in which economic growth is said to be decoupled from environmental impact, and Randers et al. 2018 for a vision for how Sustainable Development Goals can be achieved within planetary boundaries by relying heavily on green growth.

Above, I mentioned Lovelock's view that a "sustainable retreat" is now the only feasible option. With the exception of his explicit pessimism with regard to human development and the chances of ecological collapse, Lovelock's stands, with his calls for retreating to cities, massive use of nuclear energy, and an end to eating conventional food, in many ways overlap with the ecomodernist outlook. Just like the ecomodernists, Lovelock, too, favours high-tech solutions that enable us to decouple resource use from environmental impact. Unlike the ecomodernists, however, he seems to assume that human welfare is bound to deteriorate.

In a sense, ecomodernist thinking regarding technology is more in line with business-as-usual reasoning than Deep Ecologist thinking is, in that it embraces technological development rather than problematizing it. While Deep Ecology may come across as anti-modern (or post-modern) in this respect, ecomodernism is rather hyper-modern. Clearly, there are also connections between Deep Ecology's and radical environmentalism's general preference for small communities (Næss 1989; Sætreng 1993) versus ecomodernism's positive attitude towards urbanization, and their preference for low-tech and high-tech solutions respectively. Large-scale technological solutions such as nuclear power plants arguably necessitate and perpetuate an urban, high-tech lifestyle.

Bina et al. (2020: 1) discuss “techno-utopian' fantasies" that ignore "the risks of a technologically determined future" and promote ideas about "wholly new or partially renovated cities that bear little resemble to contemporary urban realities" (Bina et al. 2020: 2). They point out that for "Lewis Mumford (Mumford, 1965), the dangers of the techno-utopia could be traced back to the very origins of both the city and the idea of utopia itself" (Bina et al. 2020: 3). In the words of Mumford (1965: 279): 
[I]t is at the very beginning of urban civilization that one encounters not only the archetypal form of the city as utopia but also another coordinate utopian institution essential to any system of communal regimentation: the machine. In that archaic constellation the notion of a world completely under scientific and technological control, the dominant utopian fantasy of our present age, first becomes evident.

With its strong belief in the city and technology, ecomodernism is arguably just as utopian as Deep Ecology is, although it has fundamentally different inclinations.

Deep Ecology's preference for low-tech solutions and calls for a systematic change in how we relate to technology should not be taken to imply that Deep Ecologists are against all sorts of technological innovation. Næss (1995[1992]: 466) stresses that the "societies developing in the twenty-second century [...] will not all look like the ideal Green societies envisioned since the 60s. Many will have traits more in common with what we have today". While conspicuous consumption will occur in some of them, there "will be no political support of greed and unecological production” (Næss 1995[1992]: 466), nor for social injustice. Næss (1995[1992]: 467) envisions "big, but not dominating, centers of commerce". Entrepreneurs, Næss (1995[1992]: 467) writes, "are required in any dynamic society", and even a green society will "need enthusiasts of the extravagant, the luxurious, and the big" - but "they must not dominate". To summarize, although a majority in a future Deep Ecological society would prioritize non-material values, there would still be ample room for technological and other forms of innovation, albeit primarily in the form of social innovation (i.e. innovation that is motivated by the common good rather than private profit).

\section{Case study: Negative emission technologies}

In the context of climate change, in the $1.5^{\circ} \mathrm{C}$ report by IPCC (2018), three of four scenarios for limiting global warming to $1.5^{\circ} \mathrm{C}$ rely on negative emissions at some point in the future. In effect, these scenarios assume an overshoot in terms of emissions, followed by a period in which carbon dioxide is sucked out of the air in some way - e.g. by way of the so-called 'Direct Air Capture' - to compensate for the overshoot in hindsight. The Direct Air Capture is a form of greenhouse gas removal, which, along with Solar Radiation Management, is an example of geo-engineering (for a comprehensive review, see The Royal Society $2009^{30}$; see

30 The Royal Society 2009. Geoengineering the climate: Science, governance and uncertainty. Written by John G. Shepherd et al. (The Royal Society Policy document 10/09). The source can be accessed at https://royalsociety.org/ /media/Royal_Society_Content/policy/publications/ 2009/8693.pdf. 
also Shepherd 2012, Kruger 2015 ${ }^{31}$ ). The Royal Society (2009: 1) defines geo-engineering as "the deliberate large-scale manipulation of the planetary environment to counteract anthropogenic climate change".

As with most things high-tech, ecomodernists are in principle positive towards Direct Air Capture (Asafu-Adjaye et al. 2015: 20) as well as towards Carbon Capture and Storage (CCS) (2015: 24). "Meaningful climate mitigation", according to ecomodernists (Asafu-Adjaye et al. 2015: 21), "is fundamentally a technological challenge." The manifesto also refers positively to carbon capture and storage (CCS), highlighting "[f] ossil fuels with carbon capture and storage" (Asafu-Adjaye et al. 2015: 24). The latter is said to "provide substantial environmental benefits over current fossil or biomass energies". Negative emissions are in this context implicitly referred to once it is stated that "modern energy may allow the capture of carbon from the atmosphere to reduce the accumulated carbon that drives global warming" (Asafu-Adjaye et al. 2015: 20). This may also most fittingly be interpreted as an implicit reference to Bioenergy with Carbon Capture and Storage (BECCS), since BECCS involves both energy production and removal of carbon from the atmosphere in one and the same process. ${ }^{32}$

Although currently there are quite few large CCS projects in operation worldwide (Large Scale CCS Projects $2020^{33}$ ), the Intergovernmental Panel on Climate Change (IPCC 2005) has reviewed CCS as a climate solution, and a recent study by Ringrose and Meckel (2019) argues that engineering the thousands of wells that would be required to contribute significantly to climate mitigation is technically feasible. However, Smil (2011: 219) claims that CCS is "[t]echnically possible but not within a timeframe that would prevent $\mathrm{CO}_{2}$ from rising above $450 \mathrm{ppm}$ ”. Others, too, have raised concerns about society's increasing reliance on negative emissions at some point in the future, including on more principled grounds.

Anderson and Peters (2016: 182) claim that "[r]eliance on negative-emission concepts locks in humankind's carbon addiction". They are particularly concerned about the increasing support for Bioenergy with Carbon Capture and Storage (BECCS), which is widely assumed in emission scenarios:

31 Kruger, Tim 2015. Dimensions of geoengineering: An analysis of the Royal Society's “blob” diagram. Climate Geoengineering Governance Working Paper Series: 026 can be found at http:// www.geoengineering-governance-research.org/perch/resources/workingpaper26krugerdimensionsofgeoengineering.pdf.

32 This differs from Direct Air Capture (which does not involve energy production) and from energy production based on coal, oil or gas with carbon capture and storage (which does not involve removal of carbon from the atmosphere).

33 Large Scale CCS Projects 2020. Data from Global CCS Institute can be accessed at https://data.opendatasoft.com/explore/dataset/large-scale-carbon-capture-projectsdatabase\%40kapsarc/. 
Yet, as recognition of the ubiquitous role of BECCS in mitigation scenarios has grown, so have concerns about its deployment. Its land-use impacts could include terrestrial species losses equivalent to, at least, a $2.8^{\circ} \mathrm{C}$ temperature rise, leading to difficult trade-offs between biodiversity loss and temperature rise. (Anderson, Peters 2016: 183)

"Negative-emission technologies", the two conclude, "are not an insurance policy, but rather an unjust and high-stakes gamble. There is a real risk they will be unable to deliver on the scale of their promise" (Anderson, Peters 2016: 183). If the anticipated overshoot in emissions is not, in the end, followed by a period with negative emissions, we will fail to achieve our climate targets. This is why Anderson and Peters (2016: 183) characterize reliance on negative emissions as a "moral hazard".

Given the existence of some Carbon Capture and Storage projects over the last few decades - a majority of them run by the oil industry - many proponents of CCS claim the technology is known, proven and safe. Those who worry about whether the carbon dioxide will remain in the underground reservoirs it is injected into are met with reassurances about ongoing development of surveillance technologies that will warn us about any leakages. However, even though the key premise for CCS is that the carbon dioxide is to remain safely underground for thousands of years, the question about who will be responsible for operating these surveillance technologies for thousands of years is seldom addressed. The answer is obviously future generations of humans, which implies that it is these that will carry the practical responsibility for such a surveillance scheme, as well as the costs incurred if the storage of $\mathrm{CO}_{2}$ does not go according to the current plans.

With reference to the strong belief in technological solutions that geo-engineering rests on, Williston (2017: 199) asks "whether [...] geoengineering represents an objectionable species-level narcissism" which threatens to "cut us off from contact with anything non-human". In his view,

the temptation of geoengineering goes to the heart of what we understand as the human condition in the new epoch. For it forces us to confront a question that has been lurking in our culture since the advent of technoscience. Are we the lords and masters of the planet, finally presented with the technological means of realizing our ambitions? (Williston 2017: 215) 


\section{Complexity vs. complication}

In this subsection I will discuss notions of complexity and complication with regard to ecological and technological developments, and eventually reassess negative emission technologies in light of this discussion. As Nors Nielsen (2016: 129; see also Nors Nielsen 2007) observes, acknowledgement of ecosystem semiosis will make ecologists realize that ecosystems are "far more autonomous than we have thought hitherto"; for one thing, because all semiotic processes in ecosystems "serve to change the system state to a less probable one, i.e. to increase the thermo-dynamical information [...] of the system" (Nors Nielsen 2016: 127). This is reflected in increased complexity. The semiotic features of ecosystems also imply that for "all the interaction between the human society and nature, what we do with it or against it must be seen as interference with the [...] semiotic functions of the systems" (Nors Nielsen 2016: 129), thus potentially decreasing ecological complexity.

Ecological and biological complexity and diversity is understood in different ways, and I will not review different conceptualizations here. In Kull's (2011: 72) conception, cultural as well as biological "[d]iversity is non-quantitative by nature, i.e. it is not tantamount to the number of differences, although admittedly it can be described in this manner". Biosemioticians tend to take a qualitative approach to ecological issues. This is probably in part because semiotics in itself is tailored for qualitative rather than quantitative studies. As Stables (2012: 121) remarks, "the sign $[\ldots]$ as a unit of meaning [...] can be conceived of as unquantifiable". He refers to an "inability effectively to quantify the sign" that

[...] runs through the semiotic tradition. Even Peirce, the mathematician, could not effectively quantify the sign, and furthermore questioned the extent to which the universe can validly be seen as law-driven (and thus mathematically regular) as opposed to habit-driven (and thus mathematically approximate [...]. (Stables 2012: 121)

The Norwegian eco-philosopher Sigmund Kvaløy Sætreng, who was a radical environmentalist, though not a Deep Ecologist, introduced a distinction between complexity and complication. Sætreng (2001: 4; cf. also Sætreng 1993) defines 'complexity' as "the dynamic, irreversible, non-centrally self-steered, goal-directed, conflict-fertilized manifoldness of nature", with the human mind and body representing "a particularly refined and intricate version of that". Everything organic, in short, is complex by nature. 'Complication', on the other hand, is defined as "the static, reversible, externally and unicentrally steered, standardized structureintricacy of the machine", with the computer being "a particularly refined and 
intricate version of that" (Sætreng 2001: 4). While in this view complexity is typical of organic nature and "organic" societies, complication is typical of technology, and the more oriented a society is towards technological development, the more complicated it becomes. In this perspective, ecomodernism appears as distinctly oriented towards further complication, whereas Deep Ecology emphasizes (a return to) complexity.

Independently of Sætreng, Strum and Latour (1987) also developed a distinction between complexity and complication. In their work, however, the distinction relates first and foremost to social organization in different species. In a figure, they display the trade-off between complexity and complication, with complication specified as the "[a]bility to organize others on a large scale" (Strum, Latour 1987: 792). By that measure, modern industrial societies are the most complicated - and, according to Strum and Latour, the least socially complex when compared to baboons, hunters-gatherers, and agricultural societies. Ingold (2013:10) comments on this issue:

The more $[. .$.$] that relations are grounded in externalities, the more they can be$ factored out and their aspects disaggregated. You can focus on one thing at a time without going adrift. While this considerably simplifies the tasks of social life, it also makes it possible to assemble simple, clear-cut operations into immensely complicated structures. The overall trend in social evolution, then, involves a trade-off between complexity and complication, in which the latter rises as the former falls.

In light of this scheme, the achievements of modern industrialized societies are related to "a vastly expanded repertoire of extra-somatic resources" which "supports a massively complicated social structure while shrinking the complexity of relations to the residues of intimacy that remain within its interstices, and that have not been siphoned off into the institutional domains of politics, economics, law, religion, and so forth" (Ingold 2013: 11). In the words of Strum and Latour (1987: 794), in the case of humans social evolution has followed a path in which we have built a society "with extra-somatic resources", unlike nonhuman primates, who have built a society "with somatic resources only". Modern societies are in turn distinguished from primitive societies by increasing the emphasis on extrasomatic resources further.

I will now consider complexity and complication in the context of the total umwelt of the human species. The terms 'complexity' and 'complication' are here to be understood in a sense that combines the significance given to these terms by Sætreng $(1993,2001)$ as well as Strum and Latour (1987), thus enveloping both ecological and social aspects of complexity, and both social and technological 
aspects of complication. By a total umwelt, I mean "the sum total of the manifold phenomena appearing in the Umwelten of a particular group of subjects", such as "the total Umwelt of a species" (Tønnessen 2003: 289; cf. Uexküll 1928: 181). The total umwelt of a species can in this context be seen as a measure (in terms of structural mapping, rather than in strictly quantitative terms) of its interindividual complexity. Fig. 3 shows the historical and likely future connection between the complexity of the total human umwelt, and complication in human society.

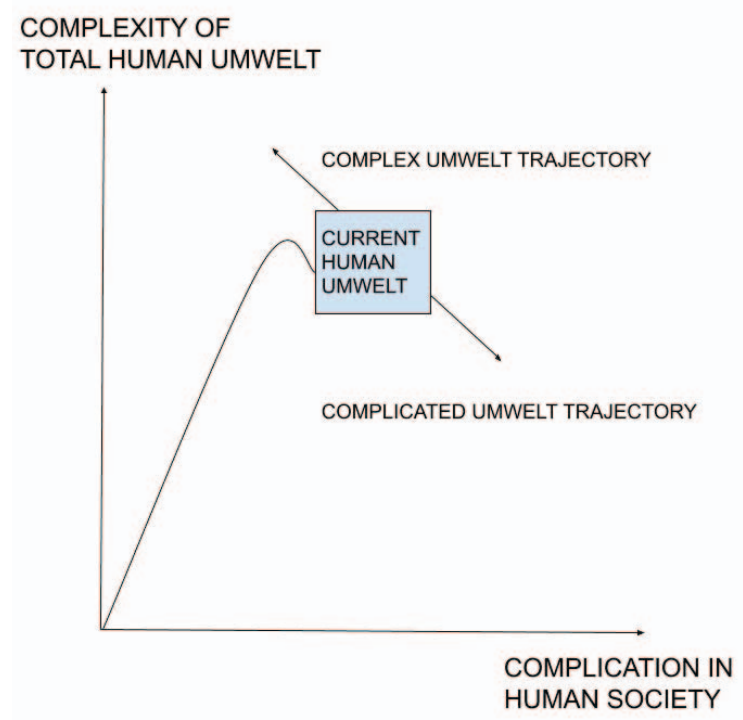

Figure 3. Complex vs. complicated umwelt trajectories.

In the figure, the curved line indicates the general direction of the umwelt trajectory of humankind in the context of complexity and complication. For a long time, the total human umwelt became more and more complex the more complication there was in human society. In other words, technological development went hand in hand with a development towards increasing complexity. As the human species increased its geographical range, it encountered a number of new environments, and mastering these led to increasing complexity for the species as a whole since it required different adaptations and skills. In practical terms this resulted in cultural diversification and innovations. At a certain point, however, complexity peaked, and started declining as human society continued to become ever more complicated, resulting in increasing standardization of human-inhabited environments 
worldwide. This is manifested, for example, in near-universal adaptation of certain technologies, and the phenomenon known as 'language death', with " $t$ thousands of the world's languages [...] vanishing at an alarming rate" (Abrams, Strogatz 2003). The current development towards lower complexity can be related to the "unification of cultural contexts" that according to Maran (2014: 87) is typical of the modern world and a key feature of globalization, and which may result in a loss of cultural, perceptual and behavioural complexity. ${ }^{34}$

In Fig. 3, two plausible future umwelt trajectories for humankind are indicated: a complex umwelt trajectory, which will involve a more complex total human umwelt but somewhat less complication in human society, and a complicated umwelt trajectory, which will involve more complication in human society but a less complex total human umwelt. An underlying assumption is that it is no longer possible to increase the complexity of the total human umwelt while simultaneously further increasing complication in human society. This assumption is in line with the bulk of experiences we have with the globalized modern world.

In simplified terms the two competing future umwelt trajectories for humankind can be associated with low-tech solutions and Deep Ecology (complex umwelt trajectory) and high-tech solutions and ecomodernism (complicated umwelt trajectory), respectively. Since reliance on negative emission technologies, treated in the previous subsection, requires planning for a high-tech developmental path, it risks locking society's long-term development into an inflexible, complicated trajectory. Under these circumstances, humankind's behavioural flexibility will be decreased because society will have bound itself to high-tech lifestyles, while making a range of low-tech and socially complex lifestyles untenable. In comparison with reliance on high-tech negative emission technologies, immediate cuts in climate gas emissions are a much safer bet, and do not rely on transferring responsibility for climate change initiated in our time to future generations. They also have the advantage of in effect enabling future generations to choose between a wider range of feasible lifestyles, thus increasing the latter's civilizational freedom, as it were.

34 It could be argued that the integration of local cultures into a more globalized culture also leads to increased complexity, by widening the sphere of influence of some cultural traits that were formerly restricted to a specific area. Similarly, even in a globalized world society, there is room for numerous international subcultures, which maintain and, in some cases, increase cultural complexity. I thank a reviewer of this paper for pointing out these nuances. 


\section{Conclusion}

By some measures human development has peaked in contemporary times. The environmental crisis emerged as standardization and depletion of human-inhabited environments worldwide started threatening the basis for existence of several non-humans and eventually of humanity as well. Since human development has to date happened at the expense of the environment, the current model of development is environmentally unsustainable.

Solving the environmental crisis evidently requires reducing the human impact on natural systems and/or making human impact more benign. Deep Ecologists and ecomodernists agree that a societal transformation is required to achieve this. What they primarily disagree on, is whether making society environmentally sustainable requires a reversion of our reliance on technological solutions (as Deep Ecologists think) or a deepening and acceleration of our reliance on technological solutions (as ecomodernists prefer). This in turn reflects contrasting attitudes to economic growth and population issues, with Deep Ecologists seeing growth in economic and population terms as contributing to the environmental crisis and preferring downscaling in both regards, while ecomodernists rather see opportunities for societal change in economic growth and are not concerned about population growth as an issue in its own right.

The different views on technology also play into different conceptions of what constitutes a good life for human beings. Unlike Deep Ecologists, who emphasize the experiential value of simpler lives in material terms, ecomodernists see high and preferably increasing standards of living as an important aspect of good lives. In consequence, what Deep Ecologists would regard as progress in human development may not qualify as progress in human development in the eyes of ecomodernists, and vice versa. Values differ the most with regard to the moral status of non-human individuals and natural systems, which is stressed by Deep Ecologists but often neglected or rejected by ecomodernists. Thus, another key difference between Deep Ecology and ecomodernism is that while Deep Ecologists firmly hold that human development should be accompanied by a good or decent development for non-humans, and that society is "sustainable" only if this is achieved, ecomodernists tend to restrict themselves to promoting human development and to regard nature primarily as humanity's basis for existence.

When assessing the societal transformation required to solve the environmental crisis, I have operated within an ecosemiotic framework drawing on umwelt theory and thus focused on how environmental change is experienced first-hand by humans as well as non-humans. I have outlined different scales in human ecology ranging from the individual to global ecology, and presented an ecosemiotic 
model of societal transformations. This model shows how socio-ecological transformations, socio-cultural transformations, and environmental change in physical terms are dynamically related to one another. I have further inquired into transformative semiotics, defined as a normatively conscious form of semiotics that relates explicitly to value issues and aims to frame a perceived need for normative transformation in semiotic terms. Moreover, I have established that ecosemiotics constitutes a form of transformative semiotics in so far as human ecology is approached critically in a political, ethical and/or another normative context. I have also discussed previous suggestions for integrating ecosemiotics with Deep Ecology, which gives ecosemiotics a clearer normative orientation.

The more theoretical parts of this article were then supplemented by outlining of possible umwelt scenarios for human ecology in the 21st century. The scenarios are focused on the four main biological functions according to Uexküll, namely what the (in this case human) organism experiences as a partner, a medium, an enemy, and food, with a business-as-usual scenario, an ecomodernist scenario and a Deep Ecology scenario presented for each of these areas. While the business-asusual scenarios tend to be unsustainable, both ecomodernist and Deep Ecology scenarios give better prospects. However, the contribution of ecomodernism towards solving the environmental crisis is in some cases undermined, or put in doubt, by its lacking recognition of the intrinsic value of non-humans. This is even more evident in the final part of the scenario development of this article, in which a distinction is made between complex (diverse, flexible, adaptable) and complicated (inflexible) umwelt trajectories, with ecomodernism tending to favour complication in social and technological matters. Here it becomes clear that Deep Ecology is better suited to protect the civilizational freedom of future generations of human beings, understood as a wider range of feasible lifestyles. Aiming for a complex, flexible umwelt trajectory for humankind in the 21st century and beyond, which allows for preserving biological as well as cultural diversity, is arguably the best way to solve the environmental crisis while safeguarding human development. In the context of climate change, an implication of this is that overreliance on high-tech negative emission technologies should be avoided. ${ }^{35}$

\footnotetext{
35 Acknowledgements: The author acknowledges his involvement in "The Greenhouse: An environmental humanities initiative at University of Stavanger" (IN-11621). An early version of this paper was presented at the 11th conference of the Nordic Association for Semiotic Studies "Anticipation and change" in Stavanger, Norway, 13-15 June 2019.
} 


\section{References}

Abrams, Daniel M.; Strogatz, Steven H. 2003. Modelling the dynamics of language death. Nature 424: 900. https://doi.org/10.1038/424900a

Anderson, Kevin; Peters, Glen 2016. The trouble with negative emissions. Science 354(6309): 182-183. https://doi.org/10.1126/science.aah4567

Bains, Paul 2001. Umwelten. Semiotica 134(1/4): 137-167. https://doi.org/10.1515/ semi.2001.020

Bar-On, Yinon M.; Phillips, Rob; Milo, Ron 2018. The biomass distribution on Earth. PNAS 115(25): 6506-6511. https://doi.org/10.1073/pnas.1711842115

Beever, Jonathan; Tønnessen, Morten 2013. "Darwin und die englische Moral": The moral consequences of Uexküll's Umwelt theory. Biosemiotics 6(3): 437-447. https://doi. org/10.1007/s12304-013-9180-x

Beever, Jonathan; Tønnessen, Morten 2017. Justifying moral standing by biosemiotic particularism. Zeitschrift für Semiotik 37(3-4): 31-53. https://doi.org/10.14464/zsem. v37i3-4.366

Bina, Olivia; Inch, Andy; Pereira, Lavínia 2020. Beyond techno-utopia and its discontents: On the role of utopianism and speculative fiction in shaping alternatives to the smart city imaginary. Futures 115: 102475. https://doi.org/10.1016/j.futures.2019.102475

Bourdieu, Pierre 1991. Language and Symbolic Power. Cambridge: Harvard University Press.

Brock, Friedrich 1939. Typenlehre und Umweltforschung: Grundlegung einer idealistischen Biologie (= Bios. Vol. 9.). Leipzig: Verlag von Johann Ambrosium Barth.

Cassirer, Ernst 1944. An Essay on Man: An Introduction to a Philosophy of Human Culture. New Haven: Yale University Press.

Ceballos, Gerardo; Ehrlich, Paul R.; Barnosky, Anthony D.; García, Andrés; Pringle, Robert M.; Palmer, Todd M. 2015. Accelerated modern human-induced species losses: Entering the sixth mass extinction. Science Advances 1(5): e1400253. https:// doi.org/10.1126/sciadv.1400253

Crist, Eileen 2015. The reaches of freedom: A response to An Ecomodernist Manifesto. Environmental Humanities 7: 245-254. https://doi.org/10.1215/22011919-3616452

Darimont, Chris T.; Fox, Caroline H.; Bryan, Heather M.; Reimchen, Thomas E. 2015. The unique ecology of human predators. Science 349(6250): 858-861. https://doi. org/10.1126/science.aac4249

Drechsler, Wolfgang 2009. Political semiotics. Semiotica 173(1/4): 73-97. https://doi. org/10.1515/SEMI.2009.003

Ellis, Erle C.; Mehrabi, Zia 2019. Half Earth: Promises, pitfalls, and prospects of dedicating half of Earth's land to conservation. Current Opinion in Environmental Sustainability 38: $22-30$.

FAO 2006. Livestock's Long Shadow: Environmental Issues and Options. Rome: FAO, Communication Division.

Fremaux, Anne; Barry, John 2019. The "good Anthropocene" and green political theory: Rethinking environmentalism, resisting ecomodernism. In: Biermann, Frank; Lövbrand, Eva (eds.), Anthropocene Encounters: New Directions in Green Political Thinking. Cambridge: Cambridge University Press, 171-190. https://doi.org/10.1017/ 9781108646673.009 
Gare, Arran 2007. The semiotics of global warming: Combating semiotic corruption. Theory and Science 9(2): 1-36.

Gare, Arran 2010. Toward an ecological civilization: The science, ethics, and politics of eco-poiesis. Process Studies 39(1): 5-38. https://doi.org/10.5840/process20103912

Gens, Jean-Claude 2013. Uexküll's Kompositionslehre and Leopold's "land ethic" in dialogue: On the concept of meaning. Sign Systems Studies 41(1): 69-81. https://doi. org/10.12697/SSS.2013.41.1.04

Griscom, Bronson W. et al. 2017. Natural climate solutions. PNAS (October 31, 2017) 114(44): 11645-11650. https://doi.org/10.1073/pnas.1710465114

Guattari, Félix 2013. Qu'est-ce que l'écosophie? (Nadaud, Stephane, ed.) Paris: Lignes \& IMEC.

Hoffmeyer, Jesper 1996. Signs of Meaning in the Universe. Bloomington: Indiana University Press.

Hoffmeyer, Jesper 2008. Semiotic scaffolding of living systems. In: Barbieri, Marcello (ed.), Introduction to Biosemiotics: The New Biological Synthesis. Dordrecht: Springer, 149166. https://doi.org/10.1007/1-4020-4814-9_6

Ingold, Tim 2013. Anthropology beyond humanity. Suomen Antropologi: Journal of the Finnish Anthropological Society 38(3): 5-23.

IPCC 2005. Carbon Dioxide Capture and Storage - Summary for Policymakers and Technical Summary. IPCC special report, Intergovernmental Panel on Climate Change. IPCC 2018. Global Warming of $1.5^{\circ} \mathrm{C}$. Intergovernmental Panel on Climate Change.

Ipsen, Guido 2006. From environment to culture: Aspects of continuity. Sign Systems Studies 34(1): 83-104.

Kopnina, Helen; Washington, Haydn; Gray, Joe; Taylor, Bron 2018. The 'future of conservation' debate: Defending ecocentrism and the Nature Needs Half movement. Biological Conservation 217: 140-148. https://doi.org/10.1016/j.biocon.2017.10.016

Kull, Kalevi 1998. Semiotic ecology: Different natures in the semiosphere. Sign Systems Studies 26(1): 344-371.

Kull, Kalevi 2010. Umwelt and modelling. In: Cobley, Paul (ed.), The Routledge Companion to Semiotics. London: Routledge, 43-56.

Kull, Kalevi 2011. Foundations for ecosemiotic deep ecology. In: Peil, Tiina (ed.), The Space of Culture - the Place of Nature in Estonia and Beyond (Approaches to Culture Theory 1). Tartu: Tartu University Press, 69-75.

Kull, Kalevi; Kotov, Kaie; Keskpaik, Riste 2004. Semiotic fundamentals of deep ecology. In: Sarapik, Virve (ed.), International Conference Culture, Nature, Semiotics: Locations IV. Abstracts. Tallinn, Tartu: Estonian Literary Museum, 26.

Latour, Bruno 2015. Fifty shades of green. Environmental Humanities 7: 219-225. https:// doi.org/10.1215/22011919-3616416

Levesque, Simon 2016. Two versions of ecosophy: Arne Næss, Félix Guattari, and their connection with semiotics. Sign Systems Studies 44(4): 511-541. https://doi. org/10.12697/SSS.2016.44.4.03

Lindström, Kati; Kull, Kalevi; Palang, Hannes 2011. Semiotic study of landscapes: An overview from semiology to ecosemiotics. Sign Systems Studies 39(2/4): 12-36. https://doi. org/10.12697/SSS.2011.39.2-4.02

Ljungberg, Christina 2001. Wilderness from an ecosemiotic perspective. Sign Systems Studies 29(1): 169-186. 
Lotman, Juri 2009. Culture and Explosion. Berlin, New York: Mouton de Gruyter.

Lovelock, James 2006. The Revenge of Gaia: Why the Earth is Fighting Back - and How we Can Still Save Humanity. Santa Barbara: Allen Lane.

Marais, Kobus 2017. "What does development stand for?" A socio-semiotic conceptualisation. Social Semiotics 29(1): 15-28. https://doi.org/10.1080/10350330.2017.1392129

Maran, Timo 2014. Place and sign. Locality as a foundational concept for ecosemiotics. In: Siewers, Alfred Kentigern (ed.), Re-Imagining Nature: Environmental Humanities and Ecosemiotics. Lewisburg: Bucknell University Press, 79-89.

Maran, Timo; Kull, Kalevi 2014. Ecosemiotics: Main principles and current developments. Geografiska Annaler, Series B: Human Geography 96(1): 41-50. https://doi.org/10.1111/ geob.12035

Meadows, Donella H.; Meadows, Dennis L.; Randers, Jørgen; Behrens, William W. 1972. The Limits to Growth. New York: Signet/New American Library.

Meadows, Donella H.; Randers, Jørgen; Meadows, Dennis 2002. Limits to Growth: The 30-Year Update. White River Junction, Vermont: Chelsea Green Publishing.

Mert, Ayşem 2019. Democracy in the Anthropocene: A new scale. In: Biermann, Frank; Lövbrand, Eva (eds.), Anthropocene Encounters: New Directions in Green Political Thinking, 128-149. Cambridge: Cambridge University Press. https://doi. org/10.1017/9781108646673.007

Mill, John Stuart 2001. On Liberty. Kitchener: Batoche Books Ltd.

Mumford, Lewis 1965. Utopia, the city and the machine. Daedalus 94(2): 271-292.

Næss, Arne 1936. Erkenntnis und wissenschaftliches Verhalten. Oslo: Det norske videnskapsakademi i Oslo.

Næss, Arne 1973. The shallow and the deep, long-range ecology movements: A summary. Inquiry 16(1): 95-100. https://doi.org/10.1080/00201747308601682

Næss, Arne 1989. Ecology, Community, and Lifestyle. (Rothenberg, David, trans., ed.). Cambridge: Cambridge University Press. https://doi.org/10.1017/CBO9780511525599

Næss, Arne 1995[1992]. Deep Ecology for the 22nd century. In: Sessions, George (ed.), Deep Ecology for the 21st Century. 463-467. [First published in Trumpeter 9(2): 86-88].

Næss, Arne 1993. The deep ecological movement: Some philosophical aspects. In: Zimmerman, Michael (ed.), Environmental Philosophy: From Animal Rights to Radical Ecology. Englewood Cliffs: Prentice Hall, 193-212.

Nobre, Carlos A.; Sampaio, Gilvan; Salazar, Luis 2007. Mudanças climáticas e Amazônia. Ciência e Cultura 59(3): 22-27.

Nors Nielsen, Søren 2007. Towards an ecosystem semiotics: Some basic aspects for a new research programme. Ecological Complexity 4: 93-101. https://doi.org/10.1016/j. ecocom.2007.04.001

Nors Nielsen, Søren 2016. Second order cybernetics and semiotics in ecological systems - where complexity really begins. Ecological Modelling 319: 119-129. https://doi. org/10.1016/j.ecolmodel.2015.08.006

Nöth, Winfried 1998. Ecosemiotics. Sign Systems Studies 26(1): 332-343.

Nöth, Winfried 2001. Ecosemiotics and the semiotics of nature. Sign Systems Studies 29(1): 71-81.

Nöth, Winfried; Kull, Kalevi 2000. Discovering ecosemiotics. Sign Systems Studies 28(1): 421-424. 
Oelschlaeger, Max 2001. Ecosemiotics and the sustainability transition. Sign Systems Studies 29(1): 219-236.

Oelschlaeger, Max 2014. Deep Ecology and the future of the wild in the Anthropocene. The Trumpeter 30(2): 231-246.

Olteanu, Alin; Rabitz, Florian; Jurkevičienè, Jurgita; Budžytė, Agnè 2019. The case for a semiotic method in Earth system science: Semantic networks of environmental research. Sign Systems Studies 47(3/4): 552-589. https://doi.org/10.12697/ SSS.2019.47.3-4.09

O’Neill, Daniel W.; Fanning, Andrew L.; Lamb., William L.; Steinberger, Julia K. 2018. A good life for all within planetary boundaries. Nature Sustainability 1: 88-95. https:// doi.org/10.1038/s41893-018-0021-4

Pinker, Steven 2019. Enlightenment Now: The Case for Reason, Science, Humanism and Progress. New York: Penguin Books.

Potter, Rebecca C. 2016. The biosemiotics of Aldo Leopold. Sign Systems Studies 44(1/2): 111-127. https://doi.org/10.12697/SSS.2016.44.1-2.07

Randers, Jørgen; Rockström, Johan; Stoknes, Per Espen; Golüke, Ulrich; Collste, David; Cornell, Sarah 2018. Transformation Is Feasible: How to Achieve the Sustainable Development Goals within Planetary Boundaries (A report to the Club of Rome). Stockholm Resilience Centre Report. https://doi.org/10.31223/OSF.IO/XWEVB

Ringrose, Philip S; Meckel, Tip A. 2019. Maturing global $\mathrm{CO}_{2}$ storage resources on offshore continental margins to achieve 2DS emissions reductions. Scientific Reports 9: 17944. https://doi.org/10.1038/s41598-019-54363-z

Sandberg, Maria; Klockars, Kristian; Wilén, Kristoffer 2019. Green growth or degrowth? Assessing the normative justifications for environmental sustainability and economic growth through critical social theory. Journal of Cleaner Production 206: 133-141. https://doi.org/10.1016/j.jclepro.2018.09.175

Sætreng, Sigmund Kvaløy 1993. Complexity and time. In: Reed, Peter; Rothenberg, David (eds.), Wisdom in the Open Air: The Norwegian Roots of Deep Ecology. Minneapolis: University of Minnesota Press, 116-146.

Sætreng, Sigmund Kvaløy 2001. Gaia versus Servoglobe. In: I et filosofisk terreng. Festskrift til Sverre Sløgedal (Filosofisk institutts publikasjonsserie nr. 43). Trondheim: NTNU.

Sayre, Nathan F. 2005. Ecological and geographical scale: Parallels and potential for integration. Progress in Human Geography 29(3): 276-290. https://doi.org/10.1191/ 0309132505ph546oa

Selg, Peeter; Ventsel, Andreas 2019. What is political semiotics and why does it matter? A reply to Janar Mihkelsaar. Semiotica 231: 27-37. https://doi.org/10.1515/sem-2018-0097

Sessions, George 2014. Deep Ecology, New Conservation, and the Anthropocene worldview. The Trumpeter 30(2): 106-114.

Shepherd, John G. 2012. Geoengineering the climate: An overview and update. Philosophical Transactions of the Royal Society: A 370: 4166-4175. https://doi.org/10. 1098/rsta.2012.0186

Smil, Vaclav 2011. Global energy: The latest infatuations. American Scientist 99: 212-219. https://doi.org/10.1511/2011.90.212

Stables, Andrew 2012. Be(com)ing Human: Semiosis and the Myth of Reason (Educational Futures 56). Rotterdam: Sense Publishers. https://doi.org/10.1007/978-94-6091-997-8 
Steffen, Will; Grinevald, Jacques; Crutzen, Paul; McNeill, John 2011. The Anthropocene: Conceptual and historical perspectives. Philosophical Transactions of the Royal Society A 369: 842-867. https://doi.org/10.1098/rsta.2010.0327

Stella, Marco; Kleisner, Karel 2010. Uexküllian Umwelt as science and as ideology: The light and the dark side of a concept. Theory in Biosciences 129(1): 39-51. https://doi. org/10.1007/s12064-010-0081-0

Stoknes, Per Espen; Rockström, Johan 2018. Redefining green growth within planetary boundaries. Energy Research \& Social Science, 44: 41-49. https://doi.org/10.1016/j. erss.2018.04.030

Strum, Shirley; Latour, Bruno 1987. Redefining the social link: From baboons to humans. Social Science Information 26(4): 783-802. https://doi.org/10.1177/ 053901887026004004

Tinnell, John 2011. Transversalising the ecological turn: Four components of Felix Guattari's ecosophical perspective. The Fibreculture Journal 18: 35-64.

Tønnessen, Morten 2003. Umwelt ethics. Sign Systems Studies 31(1): 281-299.

Tønnessen, Morten 2008. The statistician's guide to Utopia: The future of growth. TRAMES 12(2): 115-126. https://doi.org/10.3176/tr.2008.2.01

Tønnessen, Morten 2009. Umwelt transitions: Uexküll and environmental change. Biosemiotics 2(1): 47-64. https://doi.org/10.1007/s12304-008-9036-y

Tønnessen, Morten 2011. Umwelt Transition and Uexküllian Phenomenology - An Ecosemiotic Analysis of Norwegian Wolf Management. (Dissertationes Semioticae Universitatis Tartuensis 16.) Tartu: Tartu University Press.

Tønnessen, Morten 2014. Umwelt trajectories. Semiotica 198: 159-180. doi: 10.1515/sem2013-0106. https://doi.org/10.1515/sem-2013-0106

Tønnessen, Morten 2016. The semiotics of predation and the Umwelten of large predators. In: Maran, Timo; Tønnessen, Morten; Rattasepp, Silver (eds), Animal Umwelten in a Changing World - Zoosemiotic Perspectives. Tartu: Tartu University Press, 150-181.

Tønnessen, Morten 2019. What can be known about future Umwelten? The American Journal of Semiotics 35(3/4): 401-429. https://doi.org/10.5840/ajs202012359

Tønnessen, Morten 2020. Current human ecology in the Amazon and beyond: A multiscale ecosemiotic approach. Biosemiotics 13(1): 89-113. https://doi.org/10.1007/ s12304-020-09379-8

Tønnessen, Morten; Beever, Jonathan 2014. Beyond sentience: Biosemiotics as foundation for animal and environmental ethics. In: Hadley, John; Aaltola, Elisa (eds.), Animal Ethics and Philosophy: Questioning the Orthodoxy. London: Rowman \& Littlefield International, 47-62.

Uexküll, Jakob von 1921. Umwelt und Innenwelt der Tiere. (2nd ed.) Berlin: Verlag von Julius Springer.

Uexküll, Jakob von 1928. Theoretische Biologie (2nd ed.). Berlin: J. Springer.

Uexküll, Jakob von 1933[1920]. Staatsbiologie. Anatomie - Physiologie - Pathologie des Staates. Hamburg: Hanseatische Verlagsanstalt.

Uexküll, Jakob von 1982[1940]. The theory of meaning. Semiotica 42(1): 25-82. https:// doi.org/10.1515/semi.1982.42.1.25

United Nations Development Programme 2019. Human Development Report 2019. Beyond Income, Beyond Averages, Beyond Today: Inequalities in Human Development in the 21st Century. New York: UNDP. 
Willett, Walter et al. 2019. Food in the Anthropocene: The EAT-Lancet Commission on healthy diets from sustainable food systems. Lancet 393: 447-492. https://doi. org/10.1016/S0140-6736(18)31788-4

Williston, Byron 2017. The question concerning geo-engineering. Techné: Research in Philosophy and Technology 21(2/3): 199-221. https://doi.org/10.5840/techne201772166 World Commission on Environment and Development (WCED) 1987. Our Common Future. Oxford: Oxford University Press.

UN DESA 2004. World Population to 2300. New York: United Nations Department of Economic and Social Affairs, Population Division.

WWF 2018. Living Planet Report - 2018: Aiming Higher. (Grooten, Monique; Almond, Rosamunde E. A., eds.) Gland: WWF.

Zalasiewicz, Jan et al. 2016. Scale and diversity of the physical technosphere: A geological perspective. The Anthropocene Review 4(1): 9-22. https://doi.org/10.1177/ 2053019616677743

\section{Социальные изменения, необходимые для решения кризиса окружающей среды в XXI веке}

Статья знакомит с экосемиотическим подходом к двум главным проблемам, стоящим перед человечеством в XXI веке: решение эскалации экологического кризиса, а также сохранение и дальнейшее улучшение условий жизни человека. В статье предлагается экосемиотическая основа для изучения социальных преобразований и обсуждаются политические и другие нормативные аспекты того, что я называю трансбормационной семиотикой. Этот подход включает в себя социокультурные и социоэкологические события, которые исследуются с точки зрения теории умвельта и глубинной экологии. В долгосрочной перспективе развитие человеческой экологии, как оно отражается в наших изменяющихся отношениях с нечеловеческим миром, проявляется как траектория умвельта всего человечества. Таким образом, вопрос о том, как лучше всего решить экологический кризис, равнозначен вопросу о том, в каком направлении должна идти траектория умвельта в этом веке. Я описываю различные вероятные сценарии развития человеческой экологии в XXI веке, фокусируясь на варианте развития «в том же духе», экомодернистский сценарий и сценарий глубинной экологии. В заключении обсуждается различие между гибкими и негибкими путями развития.

\section{1. sajandi keskkonnakriisi lahendamiseks vajalike ühiskondlike teisenemiste ennetamine}

Artiklis tutvustatakse ökosemiootilist lähenemist kahele suurele väljakutsele, mis seisavad inimkonna ees 21. sajandil: eskaleeruvale keskkonnakriisile lahenduse leidmine ning samas inimeste elutingimuste alalhoidmine ning jätkuv parendamine. Ühiskonna teisenemise uurimisele pakutakse välja ökosemiootiline raamistus ning käsitletakse minu poolt transformatiivse semiootikana defineeritu poliitilisi ja muid normatiivseid aspekte. See hõlmab ühiskondlik-kultuurilisi ja ühiskondlik-majanduslikke arenguid, mida raamivad 


\section{2}

omailmateooria ja süvaökoloogia. Pikemas perspektiivis väljendatakse arenguid inimökoloogias, nagu need peegelduvad meie muutuvates suhetes mitteinimestega, inimkonna omailmatrajektoorina. Küsimus sellest, kuidas keskkonnakriisi kõige paremini lahendada, on seetõttu praktiliselt sama kui küsimus, millise suuna inimkonna omailmatrajektoor sel sajandil peaks võtma. Visandan 21. sajandi inimökoloogia jaoks erinevaid võimalikke omailmastsenaariume, keskendudes samamoodi-edasi stsenaariumile, ökomodernistlikule ja süvaökoloogilisele stsenaariumile. Kokkuvõtvas arutluses tehnoloogiast ja jätkusuutlikkusest sisaldab stsenaariumide edasiarendus viimaks eristust paindlike ja paindumatute arenguteede vahel. 